Marquette University

e-Publications@Marquette

Finance Faculty Research and Publications

Business Administration, College of

$1-1-2015$

Territorial Tax System Reform and Corporate Financial Policies

Matteo P. Arena

Marquette University, matteo.arena@marquette.edu

George Kutner

Marquette University, george.kutner@marquette.edu

Accepted version. Review of Financial Studies, Vol. 28, No. 8 (2015): 2250-2280. DOI. (C) 2015

Oxford University Press. Used with permission. 


\title{
Territorial Tax System Reform and Corporate Financial Policies
}

\author{
Matteo P. Arena \\ Department of Finance, Marquette University \\ Milwaukee, WI \\ George W. Kutner \\ Department of Finance, Marquette University \\ Milwaukee, WI
}

\begin{abstract}
We examine the effect of a permanent change to a country corporate income repatriation tax system on corporate financial policies. In 2009, Japan and the United Kingdom switched from a worldwide system to a territorial system for the taxation of repatriated foreign earnings, effectively reducing the tax liabilities of most multinational firms when repatriating earnings. We find that after the change firms accumulate less cash, pay out larger amounts through dividends and share repurchases, and invest less abroad. We do not find that the tax system change has significantly affected domestic investments even when controlling for capital constraints.
\end{abstract}

The system under which countries levy taxes on foreign profits repatriated to the domestic headquarters of multinational corporations recently has been the subject of a heated debate among policy makers and corporate lobbyists, due in part to its significant implications on the level of tax receipts. ${ }^{1}$ Recent studies on a temporary change in the 
earnings repatriation tax in the United States (Dharmapala, Foley, and Forbes 2011; Faulkender and Petersen 2012) show that these tax systems also affect corporate financial policies. In this study we analyze for the first time the implication of a permanent exogenous change in the taxation system of repatriated earnings on an array of financial policies. Specifically, we investigate the change from a worldwide repatriation tax system to a territorial system that took effect concurrently in the United Kingdom and Japan in 2009. This permanent change provides a unique opportunity to test the longlasting effects of a territorial tax system reform not only on corporate policies that are highly flexible, such as cash holdings and share repurchases, but also on those policies, such as dividend payments and corporate investments, which require a longer time to adjust to an exogenous shock.

Of the two systems that regulate the taxation of foreign earnings repatriated to the domestic headquarters of multinational firms most countries adopt a territorial system. Under this system, the parent country levies taxes only on corporate profits earned at home. Foreign subsidiaries' repatriated profits as intrafirm dividends are exempt. ${ }^{2}$ Under the worldwide system, used by the United States and a minority of other countries, the domestic country can instead levy corporate taxes on repatriated profits earned abroad. If the foreign corporate tax rate is smaller than the domestic corporate tax rate, a firm pays taxes to the foreign country on subsidiary income and then pays the remaining difference to the parent country upon repatriation of the profits. If, instead, the foreign tax rate is larger than the domestic tax rate, a firm pays taxes to the foreign country on subsidiary income and then receives a foreign tax credit on the difference by the parent country (Graham 2008) upon repatriation of the profits. ${ }^{3}$

The repatriation tax system adopted by a country is likely to have significant implications on the level of domestic and foreign corporate investments and corporate payout policy. Under the worldwide system, corporations can defer taxations on foreign earnings until the cash is repatriated back to the domestic country. As long as earnings remain abroad, these companies can effectively avoid domestic taxation of foreign income in a way similar to that of firms residing in territorial system countries (Markle 2013). The ability of 
firms residing in worldwide systems to indefinitely postpone cash domestic income taxes on foreign earnings is usually paired by accounting rules that allow corporations to also avoid financial accounting income tax expenses (Graham, Hanlon, and Shevlin 2011). Therefore, the worldwide system has the net effect of discouraging the transfer of earnings from a foreign subsidiary to the domestic parent, especially when the domestic country, as the United States or Japan, has a high corporate tax rate (Altshuler and Grubert 2002). Foley et al. (2007) find that U.S. firms facing higher repatriation taxes hold more cash overall.

Our study exploits the recent permanent change in the repatriation tax system in the United Kingdom and Japan. Both the United Kingdom and Japan switched from a worldwide to a territorial system at the beginning of 2009. In early December 2008, Japan issued a tax reform package that was implemented the following year. The package included a $95 \%$ foreign dividend tax exemption for foreign dividends received by Japanese corporations from foreign subsidiaries. The territorial tax system proposal was intended to promote repatriation of foreign earnings to J apan and to encourage Japanese firms to increase domestic investments. To limit further reduction in corporate tax income, Japan also enacted other transfer pricing regulations and thin capitalization rules to limit the use of debt by foreign subsidiaries (Landau et al. 2009). ${ }^{4}$

The U.K. government released a new rule for the full tax exemption of repatriated foreign subsidiary earnings on December 9 , 2008, which was then implemented in 2009. The main goal of the U.K. Treasury was to improve Britain's reputation as an attractive business location and prevent U.K. multinationals to relocate abroad.

Concurrently to the territorial tax system reform, the U.K. implemented antiavoidance measures and thin capitalization rules similar to Japan. ${ }^{5}$ In addition to the long-term effects that we study in this paper, the territorial tax system reform had the short-term effect to encourage some of the firms that moved their fiscal headquarters abroad to move back to the United Kingdom. Two of twenty-two U.K. firms that moved their headquarters abroad in the few years before the reform announced that they were considering to move back to the U.K. after the implementation of the territorial tax system. ${ }^{6}$ 
It is important to notice that during the worldwide system period accounting rules such as IAS 12 (analogous to U.S. GAAP APB 23) allowed British and Japanese multinational firms to avoid accounting recording of income tax expense related to foreign earnings on their consolidated financial statements. Therefore, avoiding the repatriation of foreign earnings not only permitted avoidance of cash income taxes but also of financial accounting tax expenses.

This study examines for the first time the corporate financial policy implications of a permanent change in a country income repatriation tax system. Previous studies have been confined to the analysis of U.S. samples focusing on a single tax system and a single financial policy decision, such as cash holdings or foreign acquisitions (e.g., Foley et al. 2007; Hanlon, Lester, and Verdi Forthcoming), or a temporary change in income repatriation taxation, such as the 2004 American J obs Creation Act (AJCA), also known as the Homeland Investment Act (Dharmapala, Foley, and Forbes 2011; Faulkender and Petersen 2012). Our examination of a permanent change to the repatriation tax system provides a unique opportunity to analyze how different is the corporate response to a lasting reform versus a temporary one for corporate financial policies that are less time variant, such as dividend payments and corporte investments.

In this study we specifically examine if the change in the repatriation tax system significantly affects the level of corporate cash holdings, the amount of dividends paid and shares repurchased by the parent company, and the amount of domestic and foreign capital expenditures. We find that Japanese and U.K. multinationals accumulate less cash overall, invest less abroad, and distribute more cash to shareholders through dividends and share repurchases after the adoption of the territorial system in 2009. Our paper is the first to analyze the impact of a change in repatriation taxes on foreign capital expenditures and to show that, everything else constant, a shift to a territorial system reduces foreign investments. Our results, however, do not show that the change in the repatriation tax system has a significant effect on the level of domestic corporate investments even when we control for the firm's availability of capital. Our results on cash holdings, payout policy, and foreign investments also have strong economic significance. For a multinational firm with average assets in our sample, a change in the Income Repatriation Tax Advantage permission has been granted for this version to appear in e-Publications@Marquette. Oxford University Press does not grant permission for this article to be further copied/distributed or hosted elsewhere without the express permission from Oxford University Press. 
coefficient from its 2006-2008 mean value of -0.0030 to zero during the 2009-2011 territorial system period causes a drop in multinational firms' cash holdings ranging from $\$ 43$ to $\$ 64$ million, an increase in dividends between $\$ 51$ and $\$ 60$ million, an increase in total net payouts between $\$ 64$ and $\$ 69$ million, and a decrease in foreign capital expenditures between $\$ 14$ and $\$ 18$ million depending on the multivariate specification (firm fixed effects or industry and year fixed effects), everything else constant. The results of this study show that, unlike the U.S. temporary tax holiday in 2004 (Dharmapala, Foley, and Forbes 2011), a permanent change of the repatriation tax system has a larger impact on dividends than on share repurchases.

The findings of this study are particularly relevant given the policy debate in the United States about a possible modification of the worldwide system or a possible switch to a territorial system in the same guise of Japan and the United Kingdom. While an analysis of the effect of this change on government tax receipts is outside of the scope of this paper, our study shows the strong impact that this policy change is likely to have on corporate financial policies of U.S. multinational firms.

Even though the shift from a worldwide system to a territorial system in both the United Kingdom and Japan took place during the great recession period, a comparison between the change in the number, operating performance, and domestic investments of multinational and domestic firms dispels concerns about a possible causation between specific changes in multinational firms and the following tax reform. Despite the fact that one of the main goals of the British reform was to create an incentive for U.K. multinational firms to maintain their headquarters in Great Britain, the number of publicly traded U.K. multinational firms actually increased by $20 \%$, whereas the number of domestic firms declined by $0.4 \%$ in the three years preceding the reform. The trend was similar in Japan, where the number of multinational firms increased by $7 \%$, whereas the number of domestic firms increased by only $0.6 \%$. The Japanese government mentioned the goal of spurring domestic investments as a main motivation of the tax reform. However, median domestic investments to total assets actually increased by $5.9 \%$ for multinational firms, while they declined by $4 \%$ for domestic firms in the three years before the reform. Moreover, whereas all firms experienced a decline in 
income before the reform due to the recession, domestic firms suffered more than multinational firms. The median operating income to total assets declined by $8 \%$ between 2006 and 2008 for domestic firms but only $3 \%$ for multinational firms. ${ }^{7}$

We control for the potential biasing effect of the recessionary years in our sample (2008 and 2009) in several ways. The main multivariate regressions include a year indicator variable and several firm characteristics that are significantly affected by the business cycle. In the robustness section we re-estimate our main multivariate tests, excluding the recessionary years. We also implement an unreported difference-in-differences estimation in which we compare the group of multinational firms affected by the tax change with a control group of firms not affected by the change (purely domestic firms) before and after the implementation of the territorial system. All these tests produce results comparable to those presented in the main multivariate analysis section of the paper. As an additional robustness test to verify that our results are not influenced by some omitted, time-varying country factors, we compare the behavior of firms facing a tax cost with firms benefitting from a tax credit upon repatriating earnings during the worldwide system period and their reaction to the territorial reform. We find that tax credit firms increase their cash holdings and decrease payouts after the reform.

It is important to note that the tax planning implemented by many multinational firms to limit taxation of foreign profits might, everything else constant, strengthen the effect of a shift from a worldwide to a territorial system on corporate financial policies. Firms can implement "double Irish" and "Dutch sandwiches" arrangements or transfer pricing schemes to significantly reduce their foreign tax liabilities. However, these tax planning strategies are mainly intended to avoid foreign taxation. If those foreign earnings are repatriated to the domestic headquarters, under the worldwide system they would be taxed at the domestic tax rate minus any tax paid in the foreign subsidiaries. Therefore, these foreign tax avoidance schemes have the net effect of increasing the difference between the effective tax rate abroad and in the domestic country and providing an even stronger motivation for a multinational firms to not repatriate foreign earnings to the domestic headquarters under the worldwide system. These firms might be likely to implement more radical changes to their permission has been granted for this version to appear in e-Publications@Marquette. Oxford University Press does not grant permission for this article to be further copied/distributed or hosted elsewhere without the express permission from Oxford University Press. 
corporate financial policies after a territorial tax reform compared with firms that do not aggressively implement foreign tax avoidance schemes. $^{8}$

Even though the territorial tax reform is a large exogenous shift in tax policy, multinational corporations have to abide by other tax rules that might affect their after-tax earnings. For example, a change in controlled foreign corporation (CFC) rules or changes in tax treaties might partially offset the effect of a territorial tax reform. Although we cannot empirically control for changes in CFC rules, we realize that they might have the effect of biasing our study against finding significant results.

\section{Hypotheses Development}

Multinational firms have to consider several possible alternatives on how to best use the profits generated by their foreign subsidiaries. Firms can maintain foreign earnings abroad to increase subsidiaries' cash holdings; they can use foreign earnings to increase investments in the subsidiary countries; or they can repatriate foreign income to increase domestic cash holdings, increase corporate payouts, embark in new domestic capital investments, or initiate acquisitions. Markle (2013) finds that multinational firms subject to territorial tax systems repatriate more income to their parent country. Altshuler and Grubert (2002) argue that firms residing in worldwide tax system countries with high corporate tax rates and with a majority of foreign subsidiaries in countries with lower tax rates tend to avoid the high taxes on repatriation by keeping foreign earnings abroad. Grubert and Mutti (2001) find that firms with manufacturing subsidiaries with effective tax rates below $10 \%$ repatriate on average only $7 \%$ of their earnings. Desai, Foley, and Hines (2001) find that a decline of repatriation tax rates of $1 \%$ is associated with an increase of $1 \%$ in intrafirm dividends for U.S. firms. Repatriation taxes can in part explain why U.S. firms hold more cash than what is predicted by standard firm characteristics (Foley et al. 2007). As documented by Foley et al. (2007) for U.S firms, we also expect J apanese and U.K. firms to hold a large quantity of cash abroad during the worldwide system to avoid taxes upon earnings repatriation. Because the territorial system reform effectively eliminates the earnings 
repatriation tax, we expect the firms in our sample to experience a decline in the level of consolidated cash as they repatriate more cash, which then can be used for corporate payouts, acquisitions, or domestic corporate investments. Therefore, we formulate our first hypothesis as follows:

Hypothesis 1: J apanese and U.K. firms that face repatriation tax costs during the worldwide tax system period hold less cash overall after the adoption of the territorial tax system.

Multinational firms can use the repatriated cash to increase payouts to shareholders in the form of dividends and share repurchases. Blouin and Krull (2009) find that firms that reported definite plans to repatriate during the AJCA tax holiday increased share repurchases more than did firms that did not repatriate. Dharmapala, Foley, and Forbes (2011) also find a significant increase in share repurchases but not in dividends during the tax holiday. The lack of significant results for dividends might be due to the time persistence of dividend policy and the limited length of the tax holiday. Because we test a permanent change to earnings repatriation tax policy, we expect the reform to also significantly affect the level of dividend payments. We state our second hypothesis as follows:

Hypothesis 2: Japanese and U.K. firms that face repatriation tax costs during the worldwide tax system period distribute more cash to shareholders by increasing both dividends and share repurchases after the adoption of the territorial tax system.

Desai et al. (2007) find that U.S. companies with attractive domestic investment opportunities are more likely to repatriate earnings when the trade-off between external financing costs and repatriation taxes favor earning repatriation. As a temporary or permanent elimination of repatriation taxes effectively lowers the cost of internal financing for firms with foreign earnings, it possibly creates an incentive to invest more domestically, especially if the firms are capital constrained. However, Dharmapala, Foley, and Forbes (2011) show that during the 2004 AJCA tax holiday, U.S. multinational firms used the temporary repatriation tax break to repurchase shares rather than to invest in new domestic projects. Faulkender and Petersen (2012), on the other hand, show that capital-constrained firms did 
invest more domestically during the tax holiday. We therefore conjecture the following.

Hypothesis 3: J apanese and U.K. capital-constrained firms that face repatriation tax costs during the worldwide tax system period invest more in new domestic projects after the adoption of the territorial tax system.

The accumulation of cash by foreign subsidiaries encouraged by the worldwide tax system can also increase investment activity in the subsidiary countries. Firms that might need to repatriate cash to invest in domestic projects or other financial activities (e.g., acquisitions) might forgo those opportunities and invest more in foreign projects. Hanlon, Lester, and Verdi (Forthcoming) show that the lockout cash due to the worldwide system increases acquisition activity and capital expenditures by foreign subsidiaries of U.S. multinational firms. ${ }^{9}$ As capital-constrained firms are likely to repatriate more cash to increase payouts or invest more domestically when repatriation taxes are eliminated (Faulkender and Petersen 2012), their foreign subsidiaries will see a decrease in their available cash, possibly forcing them to be more selective about their investment opportunities. Our fourth hypothesis is as follows.

Hypothesis 4a: J apanese and U.K. firms that face repatriation tax costs during the worldwide system period invest less in new foreign projects after the adoption of the territorial tax system.

There also exists the alternative possibility that the territorial tax reform could create an incentive for firms to invest more abroad due to the removal of repatriation tax costs that would eliminate a friction in the reallocation of foreign profits to subsidiaries located in different foreign countries. Our alternative fourth hypothesis is as follows.

Hypothesis 4b: Japanese and U.K. firms that face repatriation tax costs during the worldwide tax system period invest more in new foreign projects after the adoption of the territorial tax system. 
NOT THE PUBLISHED VERSION; this is the author's final, peer-reviewed manuscript. The published version may be accessed by following the link in the citation at the bottom of the page.

\section{Sample and Univariate Analysis}

\subsection{Sample formation and variables}

The initial sample consists of the entire population of Japanese and U.K. firms covered by WorldScope from 2006 to 2011. Consistent with previous studies, we remove financial firms and utilities. We also remove companies for which tax data or other variables used in the multivariate analyses are not available. Consistent with Foley et al. (2007), our sample includes both multinational and purely domestic firms. We categorize firms as multinational if their foreign assets are larger than zero. ${ }^{10}$ During our sample period, the statutory corporate tax rate in Japan is $40.7 \%$, which is higher than any other country with the exclusions of the United Arab Emirates and Kuwait (see Table A1). The change from the worldwide system to the territorial system has therefore potentially reduced the tax liability of all Japanese multinational firms repatriating earnings. The United Kingdom, however, has a lower statutory corporate tax rate (30\% during the 2006-2008 worldwide system period). U.K. firms with a majority of foreign subsidiary profits in countries with larger corporate tax rates enjoyed a tax credit upon the repatriation of foreign profits during the worldwide system period, credit that they lost upon the implementation of the territorial system in 2009. In this paper we are interested in investigating the effect of the change in the repatriation tax rule for firms that experienced a tax cost upon repatriation of foreign profits during the worldwide system period (all Japanese firms and a majority of U.K. firms); therefore, in our main tests we remove from our sample 258 firm-year observations of U.K. firms that were receiving a foreign repatriation tax credit during the worldwide system period. ${ }^{11}$ Our final sample consists of 8,415 firm-year observations (5,338 Japanese and 3,077 U.K.) and 1,976 unique firms.

The main independent variable of this study is the Income Repatriation Tax Advantage. Similar to Foley et al. (2007), for the period between 2006 and 2008, we compute the income repatriation tax cost by first subtracting foreign taxes from the product of a firm's foreign pretax income and its effective domestic tax rate. ${ }^{12}$ We then scale this difference by total firm assets and invert the sign. For the period between 2009 and 2011, the value taken by this variable 
depends on the domestic country of the multinational firms. For U.K. firms, the value is set to zero. In Japan instead, to reflect the $95 \%$ exemption rule, we estimate the tax variable from 2009 to 2011 by multiplying the number calculated as in the 2006-2009 period by 0.05 . We also generate an Alternative Income Repatriation Tax Advantage variable. This variable is analogous to the income repatriation tax advantage but for substituting the firm's effective domestic tax rate with the country (J apan of U.K.) corporate statutory tax rate as reported in Table $A 1$.

The control variables used in the multivariate analysis are firm characteristics that the extant literature shows to significantly affect cash holdings, payout policy, and corporate investments: Log of Total Assets, Consolidated Income/Total Assets, Market-to-Book Value of Equity, Standard Deviation of Operating Income, Leverage, Capital Expenditures/Total Assets, R\&D Expenses/Total Assets, and Payout/Total Assets. Worldscope provides all data converted in U.S. dollars. As stated above, our main sample includes multinational and domestic firms. Even excluding tax considerations, multinational firms might hold more cash, because of a longer delay between the receipt of cash and its use, and more precautionary cash holdings, because of greater overall risk generated by their international operations (Foley et al. 2007). Moreover, firms with a larger proportion of income generated abroad will proportionally pay fewer dividends if most of the foreign income is not repatriated to the domestic headquarters. We control for these possible differences with two income variables: Domestic Income/Total Assets and Foreign Income/Total Assets. The dependent variables of the different regression specifications are cash holdings, corporate investments, and payout policy variables: Cash/Net Assets, Domestic Capital Expenditures/Total Assets, Foreign Capital Expenditures/Total Assets, Dividend Payout Yield, and Net Payout Yield. Appendix A describes all the variables used in this study.

\subsection{Descriptive statistics and univariate analysis}

Table 1 presents descriptive statistics for the all variables. We provide aggregate statistics for the overall sample along with statistics for the J apanese and U.K. subsamples. The Alternative Income Repatriation Tax Advantage is more negative than the Income permission has been granted for this version to appear in e-Publications@Marquette. Oxford University Press does not grant permission for this article to be further copied/distributed or hosted elsewhere without the express permission from Oxford University Press. 
Repatriation Tax Advantage because statutory tax rates are usually higher than effective tax rates. While the median of foreign income is zero, its average is $\$ 96.43 \mathrm{M}$, which is only slightly lower than the average of domestic income ( $\$ 101.48 \mathrm{M})$. These results suggest that more than half of the sample firms are domestic, but multinational firms post a large portion of their earnings abroad. This is more pronounced for U.K. firms than for Japanese firms. The mean foreign income of U.K. firms is higher than their mean domestic income. U.K. firms also have larger market-to-book ratio, higher q, and higher foreign capital expenditures than do Japanese firms. Moreover, more than half of U.K. firms do not pay dividends or buy back shares. ${ }^{13}$ In the main multivariate analyses, we include a country dummy, and we also present the results of regressions estimated by separating U.K. and Japanese firms.

Table 1. Descriptive statistics

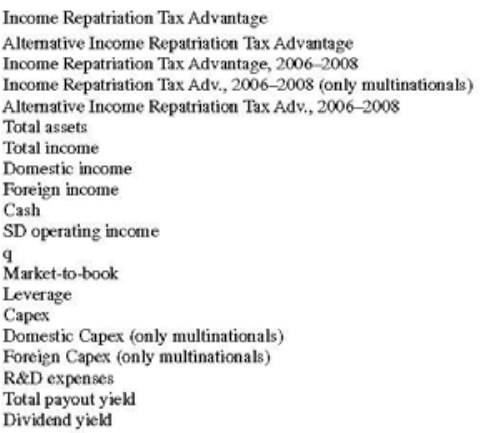

\begin{tabular}{|c|c|c|c|c|c|}
\hline \multicolumn{2}{|c|}{ Full Sample } & \multicolumn{2}{|c|}{ Japan } & \multicolumn{2}{|c|}{ United Kingdom } \\
\hline Mean & Median & Mean & Median & Mean & Median \\
\hline-0.0008 & 0.0000 & -0.0008 & 0.0000 & -0.0006 & 0.0000 \\
\hline-0.0014 & 0.0000 & -0.0012 & 0.0000 & -0.0017 & 0.0000 \\
\hline-0.0030 & 0.0000 & -0.0036 & -0.0001 & -0.0018 & 0.0000 \\
\hline-0.0059 & -0.0028 & -0.0067 & -0.0033 & -0.0051 & -0.0023 \\
\hline-0.0052 & 0.0000 & -0.0052 & -0.0004 & -0.0051 & 0.0000 \\
\hline 2346.16 & 269.26 & 2292.75 & 358.95 & 2489.64 & 73.03 \\
\hline 155.93 & 10.49 & 118.45 & 14.01 & 256.53 & 2.01 \\
\hline 101.48 & 15.60 & 10836 & 26.62 & 88.28 & 0.81 \\
\hline 96.43 & 0.00 & 73.31 & 0.00 & 140.74 & 0.00 \\
\hline 257.68 & 35.86 & 281.16 & 49.28 & 194.57 & 7.36 \\
\hline 68.47 & 8.24 & 64.61 & 9.62 & 78.92 & 4.18 \\
\hline 1.70 & 0.99 & 1.08 & 0.93 & 3.38 & 1.39 \\
\hline 1.51 & 1.23 & 1.29 & 1.11 & 2.13 & 1.56 \\
\hline 0.20 & 0.15 & 0.20 & 0.16 & 0.19 & 0.10 \\
\hline 117.86 & 5.82 & 115.62 & 8.16 & 124.19 & 1.36 \\
\hline 60.98 & 3.87 & 38.81 & 13.94 & 62.62 & 3.13 \\
\hline 139.34 & 1.85 & 44.17 & 4.25 & 147.18 & 1.32 \\
\hline 82.77 & 4.44 & 87.15 & 5.24 & 59.48 & 1.67 \\
\hline $2.80 \%$ & $1.84 \%$ & $3.00 \%$ & $2.13 \%$ & $2.25 \%$ & $0.00 \%$ \\
\hline $2.47 \%$ & $1.67 \%$ & $2.64 \%$ & $1.89 \%$ & $1.99 \%$ & $0.00 \%$ \\
\hline
\end{tabular}

This table presents means and medians of firm characteristics for the full sample (which includes both multinational and domestic firms), a subsample that includes only Japanese firms, and a subsample that includes only U.K. firms. The sample period is from 2006-2011 unless otherwise specified in the table. The variables are described in Appendix A.

Panel A of Table 2 presents univariate tests performed on two subsamples generated by splitting the sample firm-year observations between the worldwide period (2006-2008) and the territorial period (2009-2011). The sample for these univariate tests consists only of multinational firms. All multinational firms in our sample faced a repatriation cost during the worldwide period (i.e., a negative repatriation tax advantage). We present the results of t-tests of the difference of the means and Wilcoxon-Mann-Whitney nonparametric tests for the dependent variables of the multivariate analysis: 
Cash/ Net Assets, Dividend Payout Yield, and Net Payout Yield (dollar amount of dividends plus repurchases less equity issuances/total assets), Domestic Capex/Total Assets, and Foreign Capex / Total Assets. The tables also present the univariate test for the portion of dividend payers. With the exclusion of Cash/Net Assets and Domestic Capex/Assets, these univariate tests provide preliminary evidence of changes in corporate financial policies resulting from the tax system change. The t-tests of the mean show that multinational firms are more likely to pay higher dividends and pay out more overall (i.e., dividends and repurchases) in the 2009-2011 period when the tax cost of repatriating earnings effectively drops to zero for U.K. firms and to a minimal amount for Japanese firms. The percentage of dividends payers among multinational firms increases significantly from about $72 \%$ to $89 \%$ after the switch to the territorial system. Both the t-test of the mean and the Wilcoxon test suggest that domestic capital expenditures have not significantly changed after the implementation of the territorial system in 2009. Finally, both the ttest and the Wilcoxon test show that foreign capital expenditures to total assets are significantly smaller after the tax system change.

Table 2. Univariate tests

Panel A: Multinational firms during territorial system period versus worldwide system period

\begin{tabular}{|c|c|c|c|c|c|c|}
\hline & \multicolumn{2}{|c|}{$\begin{array}{c}2006-2008 \\
\text { Worldwide system }\end{array}$} & \multicolumn{2}{|c|}{$\begin{array}{c}2009-2011 \\
\text { Territorial system }\end{array}$} & \multirow{2}{*}{$\begin{array}{c}\text { Diff mean } \\
t \text {-test }\end{array}$} & \multirow{2}{*}{$\begin{array}{c}\begin{array}{c}\text { Wilcoxon } \\
\text { test }\end{array} \\
p \text {-value }\end{array}$} \\
\hline & Mean & Median & Mean & Median & & \\
\hline Cash/net assets & 0.2091 & 0.1331 & 0.2123 & 0.1423 & 0.498 & 0.489 \\
\hline Dividend yield & 0.0158 & 0.0126 & 0.0207 & 0.0163 & 0.000 & 0.186 \\
\hline Dividend payers & 0.7220 & & 0.8929 & & 0.000 & \\
\hline Net payout yield & 0.0206 & 0.0150 & 0.0267 & 0.0191 & 0,000 & 0176 \\
\hline Domestic Capex/assets & 0.0360 & 0.0171 & 0.0342 & 0.0151 & 0.664 & 0.182 \\
\hline Foreign Capex/assets & 0.0241 & 0.0119 & 0.0218 & 0.0058 & 0.087 & 0.000 \\
\hline \multicolumn{7}{|c|}{ Panel B: Change between 2010 and 2007 for multinational and domestic firms } \\
\hline & \multicolumn{2}{|c|}{$\begin{array}{l}\text { Multinational } \\
\text { firms }\end{array}$} & \multicolumn{2}{|c|}{$\begin{array}{l}\text { Domestic } \\
\text { firms }\end{array}$} & $\begin{array}{c}\text { Diff mean } \\
t \text {-test }\end{array}$ & $\begin{array}{c}\text { Wilcoxon } \\
\text { test }\end{array}$ \\
\hline & Mean & Median & Mean & Median & $p$-value & $p$-value \\
\hline$\triangle \mathrm{Cash} /$ net assets $(2010-2007)$ & -0.0005 & 0.0066 & 0.0226 & 0.0196 & 0.000 & 0.000 \\
\hline$\triangle$ Dividend yield $(2010-2007)$ & 0.0094 & 0.0047 & 0.0025 & 0.0008 & 0.029 & 0.000 \\
\hline$\triangle$ Payout yield (2010-2007) & 0.0048 & 0.0044 & 0.0036 & 0.0021 & 0.056 & 0.002 \\
\hline $\begin{array}{l}\triangle \text { Domestic Capex/assets } \\
(2010-2007)\end{array}$ & -0.0143 & -0.0028 & -0.0131 & -0.0027 & 0.848 & 0.490 \\
\hline
\end{tabular}

This table presents univariate statistics for cash, payout, and capital expenditure variables that are potentially affected by income repatriation taxes. Panel A contrasts the means and medians of these variables during the worldwide system period (2006-2008) and during the territorial system period (2009-2011). For panel A, we restrict our sample to multinational permission has been granted for this version to appear in e-Publications@Marquette. Oxford University Press does not grant permission for this article to be further copied/distributed or hosted elsewhere without the express permission from Oxford University Press. 
firms. Panel $B$ contrasts the mean and the median of the difference of each variable between its level in 2010 (during the worldwide system period) and 2007 (during the territorial system period). The last two columns of the panel table present the $p$-values of the t-test of the difference of the means and the $\mathrm{p}$-value of the Wilcoxon-Mann-Whitney nonparametric test.

The univariate test presented in panel B of Table 2 does, instead, compare the change in cash levels, payout levels, and capital expenditures between 2007 (the penultimate territorial system year) and 2010 (the second worldwide system year) for multinational and domestic firms. This comparison is particularly useful because domestic firms do not face income repatriation taxes and therefore are unaffected by the income repatriation tax system change. We define domestic firms as those firms with neither foreign assets nor foreign income.

The domestic firm sample used for this comparison is formed by domestic firms matched to their corresponding multinational firms in 2007 by total assets, market-to-book, and industry. We select matching domestic firms that have the same industry classification of the sample firms and are similar in size (total assets) and market-tobook ratio in 2007, our first sample year. In the first step of our matching procedure, we identify firms (1) with the same two-digit SIC code of the sample firms, (2) with a level of total assets between $80 \%$ and $120 \%$ of the sample firm's level, and (3) with a market-to-book ratio between $80 \%$ and $120 \%$ of the sample firm's ratio. If more than one firm meets the matching criteria for a single sample firm, we choose the one that minimizes the following formula:

$$
\left|T A_{\text {mult }}-T A_{\text {dom }}\right|+\left|M B_{\text {mult }}-M B_{\text {dom }}\right|,(1)
$$

where TAmult and TAdom are the total assets for the multinational and domestic firms and $\mathrm{MB}_{\text {mult }}$ and $\mathrm{MB}_{\text {dom }}$ are their market-to-book ratios. If we do not find any firm that meets these criteria, we repeat the process looking at firms with the same one-digit SIC code. If this search is unsuccessful, we match the firm independently from the SIC code. If we still do not find a valid match, we select the firm that minimizes formula (1) independently from the industry.

With the exclusion of Domestic Capex/Assets, these univariate tests show that our variables of interest change significantly more for permission has been granted for this version to appear in e-Publications@Marquette. Oxford University Press does not grant permission for this article to be further copied/distributed or hosted elsewhere without the express permission from Oxford University Press. 
multinational firms. Consistent with our hypotheses, the t-tests of the mean and the Wilcoxon parametric tests show that multinational firms experience a slight decrease in the mean and a slight increase in the median cash levels between 2007 and 2010, whereas domestic firms' cash levels increased significantly more. Moreover, multinational firms increased dividend and total payouts significantly more than did domestic firms between 2007 and 2010. Overall, the results presented in Table 2 provide preliminary evidence that, after the adoption of the territorial tax system of income repatriation, multinational firms are more likely to transfer income to their domestic headquarters to pay more dividends, buy back shares, and invest domestically rather than abroad. On aggregate, the annual amount paid in dividends by Japanese and U.K. multinational firms in our sample went from an average of $\$ 93$ billion in the three years preceding the reform to $\$ 108$ billion after the reform. Net repurchases increased less drastically from $\$ 32$ to $\$ 36$ billion. Domestic capital expenditures went from $\$ 25$ to $\$ 19$ billion, while foreign capital expenditures dropped from \$51 to \$22 billion. ${ }^{14}$

Figure 1 provides a complementary visual representation of the univariate results of Table 2 by illustrating the difference in annual median values for the variables of interest between multinational and domestic firms. ${ }^{15}$ While domestic firms hold larger quantities of cash/assets than multinational firms across the entire sample period, the difference becomes larger during the territorial system period. Multinational firms have lower dividend yields than did domestic firms during the worldwide system period (2006-2008) but had higher yields during the territorial system period (2009-2011). The net payout yield graph presents a similar picture. These results are consistent with the hypothesis of multinational firms increasing dividend payments during the territorial system period. As also reported earlier, earnings (and as a consequence market value) of J apanese and U.K. domestic firms was affected by the financial crisis in 2007 and the beginning of the recession in 2008 more than were earnings of multinational firms. The difference is likely due to the fact that their larger size and, for many of them, operations in developing countries less affected by the recession allowed multinational firms to reduce the negative effect of the recession. This difference can explain the larger decline in the difference in payout yields between 
NOT THE PUBLISHED VERSION; this is the author's final, peer-reviewed manuscript. The published version may be accessed by following the link in the citation at the bottom of the page.

multinational and domestic firms in 2007 and 2008 in a univariate setting.

\section{Figure 1.}
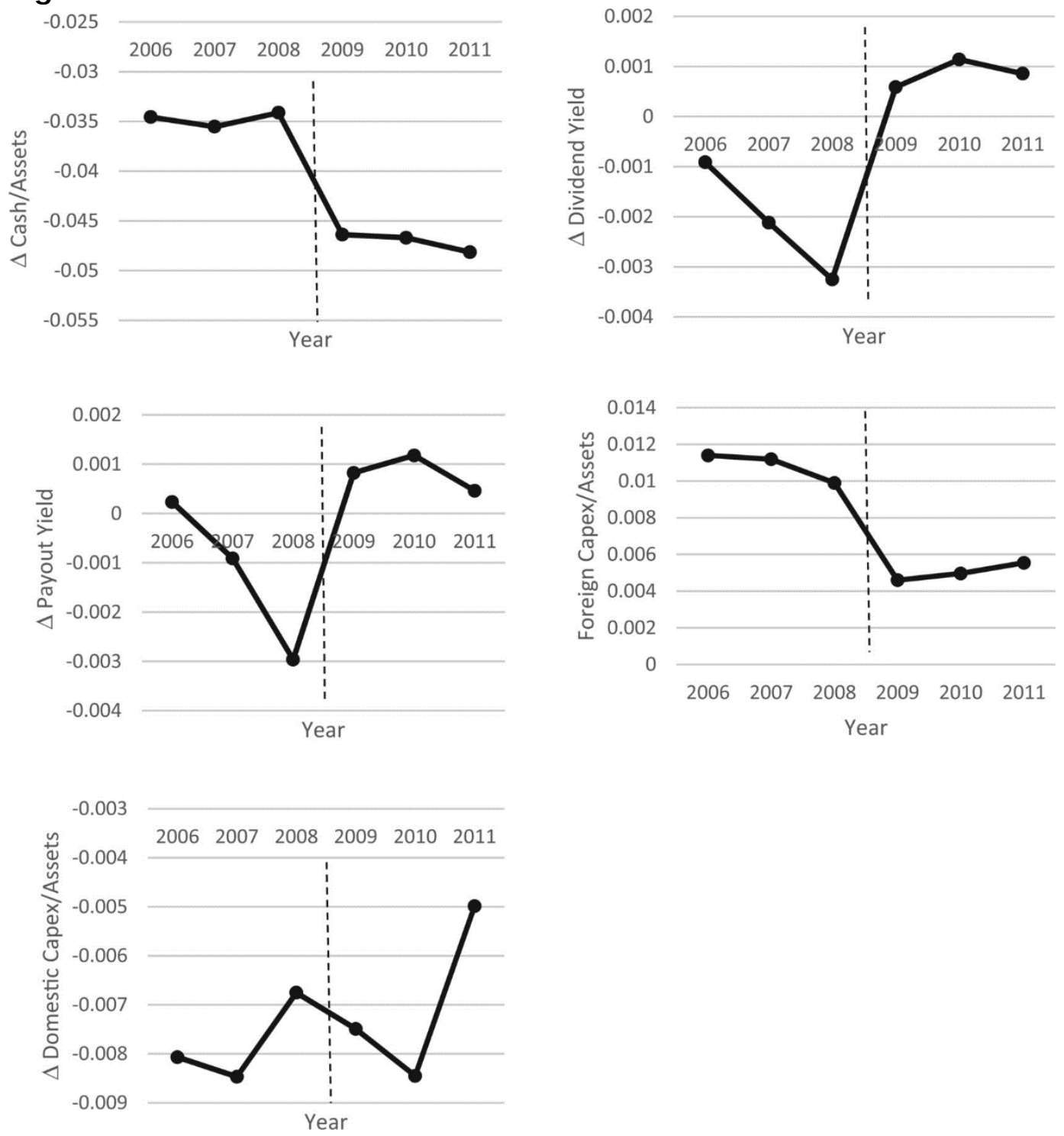

\section{Change in firm characteristics around the reform}

Difference in the annual median cash/assets, dividend yield, net payout yield, and domestic capital expenditures/assets between multinational and domestic firms. For foreign capital expenditures/assets, the figure presents the annual median values for multinational firms.

Review of Financial Studies, Vol 28, No. 8 (August 2015): pg. 2250-2280. DOI. This article is (c) Oxford University Press and permission has been granted for this version to appear in e-Publications@Marquette. Oxford University Press does not grant permission for this article to be further copied/distributed or hosted elsewhere without the express permission from Oxford University Press. 
The foreign capital expenditures/assets graph shows a marked decline in foreign investments following the tax system reform. Conversely, a comparison between the median domestic capital expenditures/assets of multinational and foreign firms does not provide evidence of a defined trend around the territorial tax reform. The increase in the difference in domestic investments in 2011 is mainly driven by a decline in domestic investments by domestic firms in that year. The reason for this decline is not due to the change in repatriation tax (the reform did not affect domestic firms) and would require an empirical investigation outside of the scope of this paper. Relevant to our study is the negligible change in the difference between 2008 and 2009. In the multivariate analysis, we control for several firm characteristics and industry, year, or firm effects to control for a multitude on nontax determinants of payouts and investments that can drive some of the changes evidenced by the graph before and after the tax reform.

\section{Main Multivariate Analysis}

Our multivariate analysis consists of several regression specifications that examine the effect of the change from the repatriation worldwide system to the territorial system on the decisions by Japanese and U.K. firms about (1) the level of cash holdings, (2) payout policy (both dividend payments and share repurchases), and (3) the amount of corporate investments abroad and in their domestic country. All regressions specifications are fixed effects regressions:

$$
y_{i t}=\beta X_{i t}+\alpha_{c}+\lambda_{j}+\gamma_{t}+\epsilon_{i t}
$$

where $y_{\text {it }}$ is one of the corporate financial policy-dependent variables listed above, $X_{i t}$ is a vector of the time-varying tax and firm-level characteristics listed in the variable section, $a c$ is a country dummy, $\lambda_{\mathrm{j}}$ are industry fixed effects, $\gamma_{\mathrm{t}}$ are year fixed effects, and $\epsilon_{\mathrm{it}}$ is the error term.

The data vary along three dimensions: time, industry, and country. The inclusion of two different countries allows us to investigate how the tax reform affects financial policies, while 
controlling for the country variation that is industry and firm specific in a way that is not possible in the typical single-country studies. When estimating Equation (2), we account for serial correlation by estimating clustered (Rogers) standard errors, which are White standard errors that account for within-firm correlation. We also estimate regression specifications with firm fixed effects in place of industry and country effects. Firm effects have the advantage of more cleanly identifying within-firms changes due to the reform. This advantage is, however, partially offset by the loss of many degrees of freedom that, in conjunction with the limited sample period, reduces the power of our tests. ${ }^{16}$

\subsection{Repatriation tax costs and cash}

Table 3 presents the results of fixed effects linear regressions with the natural logarithm of cash to net assets as the dependent variable. The first three columns present the results for regressions estimated on the full sample. In the first and third specification, we use Income Repatriation Tax Advantage as the tax variable of interest, and in the second specification, we use the Alternativel ncome Repatriation Tax Advantage variable. The first two specifications include industry and year fixed effects, and the third and fourth specifications include firm fixed effects. In the last two columns, we present the results of regressions estimated separately for Japanese and U.K. firms. 
NOT THE PUBLISHED VERSION; this is the author's final, peer-reviewed manuscript. The published version may be accessed by following the link in the citation at the bottom of the page.

Table 3. Cash holdings and income repatriation tax cost

Dependent variable: $\mathrm{Ln}$ (cash/net assets)

\begin{tabular}{lcccccc}
\hline & $(1)$ & $(2)$ & $(3)$ & & Japan & U.K. \\
\hline Income Repatriation Tax Advantage & -10.7895 & & -2.6287 & & -5.9044 & -6.0903 \\
& $(0.003)$ & & $(0.012)$ & & $(0.001)$ & $(0.049)$ \\
Alternative Income Repatriation & & -2.0665 & & -1.5436 & & \\
Tax Advantage & & $(0.030)$ & & $(0.046)$ & & \\
Log of total assets & -0.1480 & -0.1451 & -0.0569 & -0.0561 & -0.1585 & -0.1757 \\
& $(0.000)$ & $(0.000)$ & $(0.052)$ & $(0.054)$ & $(0.000)$ & $(0.000)$ \\
Domestic income/total assets & 0.0202 & 0.0252 & 0.0965 & 0.0915 & 0.1032 & -0.0870 \\
& $(0.620)$ & $(0.536)$ & $(0.018)$ & $(0.017)$ & $(0.016)$ & $(0.155)$ \\
Foreign income/total assets & -0.0211 & -0.0270 & -0.0033 & -0.0035 & 0.0145 & -0.05091 \\
& $(0.662)$ & $(0.579)$ & $(0.915)$ & $(0.913)$ & $(0.245)$ & $(0.513)$ \\
Market-to-book value of equity & 0.0001 & 0.0001 & 0.0001 & 0.0001 & 0.0039 & 0.0001 \\
& $(0.892)$ & $(0.885)$ & $(0.743)$ & $(0.748)$ & $(0.078)$ & $(0.777)$ \\
Leverage & -0.9439 & -0.9475 & -0.0429 & -0.0450 & -1.8492 & -0.2500 \\
& $(0.000)$ & $(0.000)$ & $(0.067)$ & $(0.070)$ & $(0.000)$ & $(0.000)$ \\
Capital expenditures/total assets & -2.4525 & -2.4260 & -1.7288 & -1.7128 & -2.3805 & -1.6624 \\
& $(0.000)$ & $(0.000)$ & $(0.000)$ & $(0.000)$ & $(0.000)$ & $(0.000)$ \\
R\&D expenses/total assets & 2.2716 & 2.2789 & 0.3713 & 0.3754 & 2.4044 & 1.9395 \\
Payout/total assets & $(0.000)$ & $(0.000)$ & $(0.022)$ & $(0.020)$ & $(0.000)$ & $(0.000)$ \\
& -3.6801 & -3.6890 & -0.6842 & -0.6877 & -0.2356 & -0.8662 \\
SD of operating income & $(0.000)$ & $(0.000)$ & $(0.019)$ & $(0.018)$ & $(0.004)$ & $(0.000)$ \\
Intercept & 0.0001 & 0.0001 & 0.0006 & 0.0005 & 0.0003 & 0.0001 \\
& $(0.000)$ & $(0.000)$ & $(0.000)$ & $(0.000)$ & $(0.000)$ & $(0.083)$ \\
\hline Country fixed effect & -1.5607 & -1.6184 & -0.6371 & -0.6854 & -0.6517 & -2.614 \\
Industry fixed effects & $(0.059)$ & $(0.051)$ & $(0.086)$ & $(0.086)$ & $(0.056)$ & $(0.109)$ \\
Firm fixed effects & yes & yes & no & no & no & no \\
\hline N & yes & yes & no & no & yes & yes \\
Adj. $R^{2}$ & no & no & yes & yes & no & no \\
\hline & 8,415 & 8,415 & 8,415 & 8,415 & 5,338 & 3,077 \\
& 0.401 & 0.396 & 0.623 & 0.615 & 0.321 & 0.302 \\
\hline
\end{tabular}

This table presents the coefficients of fixed effect regressions with the logarithm of cash divided by net assets as the dependent variable. The first four columns present the results for regressions, including all observations. The fifth column present results for Japanese firms, whereas the sixth column presents results for U.K. firms. All variables are described in Appendix A. The regressions include year, country, and industry or firm fixed effects. p-values, obtained with standard errors corrected for clustering of errors by firm, are presented in parentheses.

All these specifications present a consistent picture. Both repatriation tax advantage variable coefficients are negative and significant. After 2008, when firms were exempted from taxes upon repatriation of income from lower tax rate countries because of the switch to a territorial tax system, U.K. and J apanese firms significantly accumulated less cash. This result is consistent with our first hypothesis and confirms the result obtained by Foley et al. (2007) for U.S. corporations. This result also has economic significance. If the Income Repatriation Tax Advantage in the first specification goes from

Review of Financial Studies, Vol 28, No. 8 (August 2015): pg. 2250-2280. DOI. This article is (c) Oxford University Press and permission has been granted for this version to appear in e-Publications@Marquette. Oxford University Press does not grant permission for this article to be further copied/distributed or hosted elsewhere without the express permission from Oxford University Press. 
its 2006-2008 mean value of -0.0030 to effectively zero during the 2009-2011, cash holdings for a multinational firms with average assets drop $\$ 64 \mathrm{M}$, according to the industry fixed effect specification, and $\$ 43 \mathrm{M}$, according to the firm fixed effect specification, everything else constant.

Consistent with previous studies about cash holdings determinants (e.g., et al. 1999), larger companies and companies with more debt, more capital expenditures, fewer R\&D expenses, and larger payouts (dividends and share repurchases) hold significantly less cash. The positive and significant coefficient of SD of operating income suggests that the firms in our sample accumulate more cash when faced with more uncertainty, consistent with what Arena and Julio (2014) show for U.S. corporations.

\subsection{Repatriation tax cost and corporate payouts}

Cash repatriated to the domestic headquarters might be used by corporations to increase corporate payouts. In Table 4 we analyze the effect of income repatriation tax costs on dividends; in Table 5 we analyze the effect of the tax reform on the net share repurchase yield (share repurchase amount minus new share issuance amount dividend by market capitalization); and in Table 6 we report the effect of income repatriation tax costs on total payouts (dividends and net share repurchases). Because of a mass of observations at zero, due to numerous firms in the sample that do not pay dividends or repurchase shares, we estimate Tobit regressions. Standard firm effects Tobit regressions, due to the multitude of firm fixed effects, do not provide consistent results because fixed effects cannot be conditioned out of the likelihood. Therefore, for the firm fixed effects specifications, we use Honoré (1992) semiparametric estimator for fixed effect Tobit models known as trimmed least absolute deviation (LAD). The LAD estimator is consistent and asymptotically normal in firm effects specifications. 
NOT THE PUBLISHED VERSION; this is the author's final, peer-reviewed manuscript. The published version may be accessed by following the link in the citation at the bottom of the page.

Table 4. Dividend payout yield and income repatriation tax cost

Dependent variable: Dividend payout yield

\begin{tabular}{lcccccc}
\hline & $(1)$ & $(2)$ & $(3)$ & $(4)$ & Japan & U.K. \\
\hline Income Repatriation Tax Advantage & 0.5220 & & 0.1318 & & 0.1710 & 0.4897 \\
& $(0.002)$ & & $(0.014)$ & & $(0.001)$ & $(0.056)$ \\
Alternative Income Repatriation Tax Advantage & & 0.1608 & & 0.2252 & & \\
& & $(0.002)$ & & $(0.008)$ & & \\
Log of total assets & 0.0057 & 0.0055 & 0.0036 & 0.0041 & 0.0003 & 0.0414 \\
& $(0.000)$ & $(0.000)$ & $(0.002)$ & $(0.000)$ & $(0.068)$ & $(0.000)$ \\
Domestic income/total assets & 0.1001 & 0.0985 & 0.0022 & 0.0021 & 0.0014 & 0.4298 \\
& $(0.000)$ & $(0.000)$ & $(0.051)$ & $(0.053)$ & $(0.093)$ & $(0.000)$ \\
Foreign income/total assets & 0.1150 & 0.1245 & 0.0015 & 0.0018 & 0.0009 & 0.5243 \\
& $(0.000)$ & $(0.000)$ & $(0.099)$ & $(0.095)$ & $(0.224)$ & $(0.000)$ \\
Market-to-book value of equity & -0.0001 & -0.0001 & -0.0001 & -0.0001 & -0.0006 & -0.0004 \\
& $(0.179)$ & $(0.170)$ & $(0.512)$ & $(0.522)$ & $(0.123)$ & $(0.332)$ \\
Leverage & -0.0144 & -0.0137 & -0.0012 & -0.0011 & -0.0098 & -0.1932 \\
& $(0.000)$ & $(0.000)$ & $(0.061)$ & $(0.063)$ & $(0.000)$ & $(0.000)$ \\
Capital expenditures/total assets & 0.0015 & -0.0009 & -0.0106 & -0.0091 & 0.0089 & 0.0219 \\
& $(0.921)$ & $(0.952)$ & $(0.576)$ & $(0.634)$ & $(0.153)$ & $(0.809)$ \\
R\&D expenses/total assets & -0.1361 & -0.1355 & -0.0185 & -0.0181 & -0.0176 & -0.5484 \\
& $(0.000)$ & $(0.000)$ & $(0.341)$ & $(0.364)$ & $(0.081)$ & $(0.000)$ \\
SD of operating income & -0.0001 & -0.0001 & -0.0001 & -0.0001 & -0.0001 & -0.0001 \\
& $(0.002)$ & $(0.002)$ & $(0.216)$ & $(0.204)$ & $(0.183)$ & $(0.093)$ \\
Intercept & -0.2167 & -0.2135 & 0.0290 & 0.0297 & 0.0132 & -0.0503 \\
& $(0.997)$ & $(0.998)$ & $(0.000)$ & $(0.000)$ & $(0.108)$ & $(0.989)$ \\
\hline Country fixed effect & yes & yes & no & no & no & no \\
Industry fixed effects & yes & yes & no & no & yes & yes \\
Firm fixed effects & no & no & yes & yes & no & no \\
\hline N & 8,415 & 8,415 & 8,415 & 8,415 & 5,338 & 3,077 \\
Pseudo $R^{2}$ & 0.454 & 0.441 & 0.589 & 0.605 & 0.453 & 0.412 \\
\hline
\end{tabular}

This table presents the coefficients of fixed effect Tobit regressions with the dividend payout yield as the dependent variable. The firm fixed effects specifications (3) and (4) are estimated with the Honoré's (1992) trimmed least absolute deviation (LAD) estimator. The dividend payout yield is the firm's annual dividend payments divided by its year-end market value. The first four columns present the results for regressions including all observations. The fifth column present results for J apanese firms, while the sixth column presents results for U.K. firms. All variables are described in Appendix A. The regressions include year, country and industry or firm fixed effects. p-values, obtained with standard errors corrected for clustering of errors by firm, are presented in parentheses. 
NOT THE PUBLISHED VERSION; this is the author's final, peer-reviewed manuscript. The published version may be accessed by following the link in the citation at the bottom of the page.

Table 5. Net repurchase payout yield and income repatriation tax cost

Dependent variable: Net repurchase yield

\begin{tabular}{lcccccc}
\hline & $(1)$ & $(2)$ & $(3)$ & $(4)$ & Japan & U.K. \\
\hline Income Repatriation Tax Advantage & 0.2423 & & 0.0834 & & 0.3069 & 0.1350 \\
& $(0.051)$ & & $(0.065)$ & & $(0.012)$ & $(0.534)$ \\
Alternative Income Repatriation Tax Advantage & & 0.2363 & & 0.0695 & & \\
& & $(0.052)$ & & $(0.071)$ & & \\
Log of total assets & 0.0047 & 0.0047 & 0.0018 & 0.0016 & 0.0011 & 0.0100 \\
& $(0.000)$ & $(0.000)$ & $(0.089)$ & $(0.090)$ & $(0.023)$ & $(0.000)$ \\
Domestic income/total assets & 0.0499 & 0.0498 & 0.0001 & 0.0001 & 0.0226 & 0.1034 \\
& $(0.000)$ & $(0.000)$ & $(0.915)$ & $(0.912)$ & $(0.016)$ & $(0.000)$ \\
Foreign income/total assets & 0.0585 & 0.0599 & 0.0019 & 0.0019 & 0.0476 & 0.1013 \\
& $(0.000)$ & $(0.000)$ & $(0.717)$ & $(0.716)$ & $(0.002)$ & $(0.000)$ \\
Market-to-book value of equity & -0.0001 & -0.0001 & -0.0001 & -0.0001 & -0.0001 & -0.0001 \\
& $(0.475)$ & $(0.476)$ & $(0.907)$ & $(0.906)$ & $(0.616)$ & $(0.611)$ \\
Leverage & -0.0119 & -0.0116 & -0.0020 & -0.0020 & -0.0073 & -0.0538 \\
& $(0.001)$ & $(0.001)$ & $(0.548)$ & $(0.549)$ & $(0.046)$ & $(0.000)$ \\
Capital expenditures/total assets & -0.0675 & -0.0677 & -0.0150 & -0.0098 & -0.0672 & -0.0299 \\
& $(0.000)$ & $(0.000)$ & $(0.051)$ & $(0.108)$ & $(0.000)$ & $(0.417)$ \\
R\&D expenses/total assets & -0.0776 & -0.0772 & -0.0248 & -0.0247 & -0.0185 & -0.1321 \\
& $(0.000)$ & $(0.000)$ & $(0.370)$ & $(0.372)$ & $(0.479)$ & $(0.000)$ \\
SD of operating income & -0.0001 & -0.0001 & -0.0001 & -0.0001 & -0.0001 & -0.0001 \\
& $(0.690)$ & $(0.622)$ & $(0.092)$ & $(0.094)$ & $(0.660)$ & $(0.162)$ \\
Intercept & -0.0737 & -0.0697 & 0.0354 & 0.0355 & -0.0394 & -0.1184 \\
& $(0.999)$ & $(0.999)$ & $(0.000)$ & $(0.000)$ & $(0.008)$ & $(0.999)$ \\
\hline Country fixed effect & yes & yes & no & no & no & no \\
Industry fixed effects & yes & yes & no & no & yes & yes \\
Firm fixed effects & no & no & yes & yes & no & no \\
\hline N & 8,415 & 8,415 & 8,415 & 8,415 & 5,338 & 3,077 \\
Pseudo $R^{2}$ & 0.347 & 0.341 & 0.384 & 0.377 & 0.321 & 0.305 \\
\hline
\end{tabular}

This table presents the coefficients of fixed effect Tobit regressions with the net repurchase payout yield as the dependent variable. The firm fixed effects specifications (3) and (4) are estimated with the Honoré's (1992) trimmed least absolute deviation (LAD) estimator. The net repurchase payout yield is the firm's annual share repurchase amount minus the share issuance amount divided by its year-end market value. The first four columns present the results for regressions including all observations. The fifth column present results for Japanese firms, while the sixth column presents results for U.K. firms. All variables are described in Appendix A. The regressions include year, country and industry or firm fixed effects. p-values, obtained with standard errors corrected for clustering of errors by firm, are presented in parentheses. 
NOT THE PUBLISHED VERSION; this is the author's final, peer-reviewed manuscript. The published version may be accessed by following the link in the citation at the bottom of the page.

Table 6. Net payout yield and income repatriation tax cost

Dependent variable: Net payout yield

\begin{tabular}{|c|c|c|c|c|c|c|}
\hline & (1) & (2) & (3) & (4) & Japan & U.K. \\
\hline Income Repatriation Tax Advantage & $\begin{array}{r}0.5949 \\
(0.003)\end{array}$ & & $\begin{array}{r}0.2184 \\
(0.012)\end{array}$ & & $\begin{array}{r}0.2680 \\
(0.000)\end{array}$ & $\begin{array}{r}0.1200 \\
(0.087)\end{array}$ \\
\hline $\begin{array}{l}\text { Alternative Income Repatriation } \\
\text { Tax Advantage }\end{array}$ & & $\begin{array}{r}0.2034 \\
(0.001)\end{array}$ & & $\begin{array}{r}0.3049 \\
(0.007)\end{array}$ & & \\
\hline Log of total assets & $\begin{array}{r}0.0063 \\
(0.000)\end{array}$ & $\begin{array}{r}0.0061 \\
(0.000)\end{array}$ & $\begin{array}{r}0.0135 \\
(0.000)\end{array}$ & $\begin{array}{l}0.0136 \\
(0.000)\end{array}$ & $\begin{array}{l}0.0030 \\
(0.324)\end{array}$ & $\begin{array}{c}0.206 \\
(0.000)\end{array}$ \\
\hline Domestic income/total assets & $\begin{array}{r}0.1065 \\
(0.000)\end{array}$ & $\begin{array}{r}0.1052 \\
(0.000)\end{array}$ & $\begin{array}{r}0.0152 \\
(0.072)\end{array}$ & $\begin{array}{l}0.00151 \\
(0.072)\end{array}$ & $\begin{array}{r}.0019 \\
(0.775)\end{array}$ & $\begin{array}{r}0.2539 \\
(0.000)\end{array}$ \\
\hline Foreign income/total assets & $\begin{array}{r}0.1309 \\
(0.000)\end{array}$ & $\begin{array}{r}0.1430 \\
(0.000)\end{array}$ & $\begin{array}{r}0.0104 \\
(0.337)\end{array}$ & $\begin{array}{l}0.0106 \\
(0.334)\end{array}$ & $\begin{array}{r}0.0042 \\
(0.717)\end{array}$ & $\begin{array}{r}0.2749 \\
(0.000)\end{array}$ \\
\hline Market-to-book value of equity & $\begin{array}{r}-0.0001 \\
(0.152)\end{array}$ & $\begin{array}{r}-0.0001 \\
(0.145)\end{array}$ & $\begin{array}{r}-0.0001 \\
(0.761)\end{array}$ & $\begin{array}{r}-0.0001 \\
(0.762)\end{array}$ & $\begin{array}{r}-0.0007 \\
(0.000)\end{array}$ & $\begin{array}{r}-0.0001 \\
(0.496)\end{array}$ \\
\hline Leverage & $\begin{array}{r}-0.0129 \\
(0.002)\end{array}$ & $\begin{array}{r}-0.0122 \\
(0.003)\end{array}$ & $\begin{array}{r}-0.0089 \\
(0.091)\end{array}$ & $\begin{array}{r}-0.0088 \\
(0.092)\end{array}$ & $\begin{array}{c}-0.0091 \\
(0.001)\end{array}$ & $\begin{array}{r}0.0677 \\
(0.001)\end{array}$ \\
\hline Capital expenditures/total assets & $\begin{array}{c}-0.0286 \\
(0.106)\end{array}$ & $\begin{array}{c}-0.0316 \\
(0.075)\end{array}$ & $\begin{array}{r}-0.0133 \\
(0.666)\end{array}$ & $\begin{array}{r}-0.0059 \\
(0.401)\end{array}$ & $\begin{array}{r}-0.0073 \\
(0.545)\end{array}$ & $\begin{array}{r}-0.0501 \\
(0.338)\end{array}$ \\
\hline $\mathrm{R} \& \mathrm{D}$ expenses/total assets & $\begin{array}{r}-0.1373 \\
(0.000)\end{array}$ & $\begin{array}{r}-0.1374 \\
(0.000)\end{array}$ & $\begin{array}{r}-0.1025 \\
(0.028)\end{array}$ & $\begin{array}{r}-0.1029 \\
(0.027)\end{array}$ & $\begin{array}{r}-0.0194 \\
(0.304)\end{array}$ & $\begin{array}{r}-0.3066 \\
(0.000)\end{array}$ \\
\hline SD of operating income & $\begin{array}{c}-0.0001 \\
(0.017)\end{array}$ & $\begin{array}{c}-0.0001 \\
(0.015)\end{array}$ & $\begin{array}{c}-0.0001 \\
(0.000)\end{array}$ & $\begin{array}{c}-0.0001 \\
(0.121)\end{array}$ & $\begin{array}{c}-0.0001 \\
(0.356)\end{array}$ & $\begin{array}{r}-0.0001 \\
(0.210)\end{array}$ \\
\hline Intercept & $\begin{array}{r}-0.2550 \\
(0.998)\end{array}$ & $\begin{array}{r}-0.2394 \\
(0.998)\end{array}$ & $\begin{array}{l}0.0 .326 \\
(0.001)\end{array}$ & $\begin{array}{r}0.0329 \\
(0.001)\end{array}$ & $\begin{array}{c}0.0158 \\
(0.060)\end{array}$ & $\begin{array}{r}-0.5896 \\
(0.998)\end{array}$ \\
\hline Country fixed effect & yes & yes & no & no & no & no \\
\hline Industry fixed effects & yes & yes & no & no & yes & yes \\
\hline Firm fixed effects & no & no & yes & yes & no & no \\
\hline $\mathrm{N}$ & 8,415 & 8,415 & 8,415 & 8,415 & 5,338 & 3,077 \\
\hline Pseudo $R^{2}$ & 0.438 & 0.420 & 0.612 & 0.623 & 0.453 & 0.412 \\
\hline
\end{tabular}

This table presents the coefficients of fixed effect Tobit regressions with the total payout yield as the dependent variable. The firm fixed effects specifications (3) and (4) are estimated with the Honoré's (1992) trimmed least absolute deviation (LAD) estimator. The net payout yield is the firm's annual dividend payments plus net share repurchase amount minus equity issuance, all divided by its year-end market value. The first four columns present the results for regressions, including all observations. The fifth column present results for Japanese firms, and the sixth column presents results for U.K. firms. All variables are described in Appendix A. The regressions include year, country, and industry or firm fixed effects. p-values, obtained with standard errors corrected for clustering of errors by firm, are presented in parentheses.

The results presented in Table 4 show that both proxies for the repatriation tax advantage are positive and significantly related to the dividend payout yield. The results are also robust to the inclusion of firm fixed effects. This result is consistent with our hypothesis that the exemption from repatriation taxes due to the enactment of the territorial system had the significant effect of increasing dividend payments by U.K. and J apanese corporations. The coefficient of the Income Repatriation Tax Advantage implies a large change in dividend

Review of Financial Studies, Vol 28, No. 8 (August 2015): pg. 2250-2280. DOI. This article is (c) Oxford University Press and permission has been granted for this version to appear in e-Publications@Marquette. Oxford University Press does not grant permission for this article to be further copied/distributed or hosted elsewhere without the express permission from Oxford University Press. 
yield after the implementation of the territorial system. If the Income Repatriation Tax Advantage in the industry fixed effect specification (1) (firm fixed effect specification 3) goes from its 2006-2008 mean value of -0.0030 to effectively zero during the 2009-2011, the dividend yield increases from $1.67 \%$ to $1.93 \%$ (from $1.69 \%$ to $1.91 \%)$, everything else constant, at the median. This change in yield corresponds to an increase of $\$ 60 \mathrm{M}(\$ 51 \mathrm{M})$ in dividends for a multinational firm with average assets and market-to-book ratio in our sample. These results are remarkable considering that both in the United Kingdom and in Japan the stock market experienced a significant decline in value between 2006 and 2008, followed by a gain between 2009 and 2011. ${ }^{17}$ The slightly lower significance of the Income Repatriation Tax Advantage variable coefficient in the U.K.only regression can be explained by a larger relative increase in stock market returns in the United Kingdom, compared with Japan, between 2009 and 2006 and by a smaller number of dividend-paying firms in any given year in the United Kingdom than in Japan.

The results of Table 4 differ from what Dharmapala, Foley, and Forbes (2011) find for dividend payments. Because of the significant lasting consequences that changes in dividend payments have on firm value, firms smooth dividends, while exploiting the flexibility of share repurchases for fast adjustment in payouts (Skinner (2008)). The results of Table 4 show that a permanent exogenous change in the tax system has a significant effect on the less flexible dividend policy.

The control variables have coefficients consistent with the findings of previous studies that analyze the determinants of payout policy (Grullon et al. (2011); Hoberg and Prabhala (2009)). Larger companies, more profitable companies, and companies with lower leverage, lower R\&D expenses, and less income volatility distribute more cash to their shareholders in the form of dividends.

The results of the net repurchase yield regressions in Table 5 provide useful complementary information to the results of Table 4. For the regressions estimated with the full sample, the Tax Advantage coefficients are positive and significant. This result is consistent with the hypothesis that the territorial tax reform has increased the level of share repurchases as a consequence of reducing the cost of repatriating profits to the firm's domestic headquarters. However, the

Review of Financial Studies, Vol 28, No. 8 (August 2015): pg. 2250-2280. DOI. This article is (c) Oxford University Press and permission has been granted for this version to appear in e-Publications@Marquette. Oxford University Press does not grant permission for this article to be further copied/distributed or hosted elsewhere without the express permission from Oxford University Press. 
statistical significance of the Tax Advantage coefficients is lower than in the dividend regressions. A comparison of the results of Tables 4 and 5 suggests that the permanent change in the tax code had a more significant effect on dividend policy. The results for the U.K. sample regression show that the Income Repatriation Tax Advantage coefficient is not significant. It is likely that the tax reform did not significantly affect share repurchase levels in the United Kingdom due to other strict regulations that strongly limit the efficacy of share repurchase programs for British firms. Rau and Vermaelen (2002) show that, due to several reasons, share repurchase activity by U.K. firms is minimal compared with U.S. firms. The Model Code prevents U.K. firms from repurchasing shares in the two-month period prior to the filing of annual earnings and semiannual earnings and in the one month before the release of quarterly results. Moreover, U.K. firms are required to cancel all repurchased shares. This rule drastically reduces the flexibility of share repurchases in the United Kingdom because it prevents the creation of treasury stock (i.e., shares that are repurchased but can be reissued without shareholder approval). ${ }^{18}$

The results of the net payout yield regressions presented in Table 6 are consistent with the results of the dividend and share repurchase regressions. The exemption from income repatriation taxes also has a positive and significant effect of total net payouts. A change of the Income Repatriation Tax Advantage in the industry fixed effect specification ( 1 ) (firm fixed effect specification 3) from its 2006-2008 mean value of -0.0030 to zero during the 2009- 2011 territorial system period causes a $16 \%(15 \%)$ increase in net payout yield from $1.84 \%$ to $2.14 \%$ ( $1.84 \%$ to $2.11 \%$ ), everything else constant. This change in yield corresponds to an increase of \$69 $\mathrm{M}(\$ 64 \mathrm{M})$ in net payouts for a multinational firm with average assets and market-tobook ratio in our sample. The coefficients of control variables have the expected sign consistent with the dividend and repurchase regressions results of Tables 4 and 5 and previous studies on payout policy. For a multinational firm with average assets, the results of the firm fixed effect regression suggest that $\$ 51 \mathrm{M}$ out of the $\$ 64 \mathrm{M}$ increase in payouts comes from an increase in dividends. This result provides evidence of the stronger effect that the permanent tax reform had on dividends than on repurchases. 


\subsection{Repatriation tax cost and corporate investments}

The payout results presented in the previous tables show that firms use at least a portion of the cash repatriated to the domestic country to increase distributions to shareholders in the form of dividends and share repurchases. Some of the repatriated cash also could be possibly used to increase domestic investments. We test this hypothesis by estimating fixed effects regressions with domestic capital expenditures over assets as the dependent variables. ${ }^{19}$ Table 7 presents the results. Neither repatriation tax proxy in any of the specifications has a significant coefficient, suggesting that after the implementation of the territorial system U.K. and J apanese firms do not use the additional cash repatriated to their domestic country to increase domestic investments. The third specification of Table 7 includes an interaction variable between the tax advantage variable and a measure of capital constraint similar to the one used by Faulkender and Petersen (2012). Capital Constrained is defined as the percentage of the previous four years in which operating cash flows (operating income after tax) were lower than capital expenditures. Capital-constrained firms are possibly more likely to increase domestic investment instead of increasing payouts when allowed to repatriate earnings at no additional tax cost. However, our results are not consistent with this hypothesis. The coefficient of the interaction variable between the tax advantage (alternative tax advantage) variable and the capital-constrained variable is not statistically significant. The coefficients of the control variables show that smaller firms and firms with greater domestic profits, with the exclusion of the U.K.-only sample, invest proportionally more in their domestic country. 
NOT THE PUBLISHED VERSION; this is the author's final, peer-reviewed manuscript. The published version may be accessed by following the link in the citation at the bottom of the page.

Table 7. Domestic investments and income repatriation tax cost

\begin{tabular}{lccccccc}
\hline & $(1)$ & $(2)$ & $(3)$ & $(4)$ & $(5)$ & Japan & U.K. \\
\hline Income Repatriation Tax Advantage & 0.3727 & & 0.4078 & 0.0120 & & 0.3049 & 0.4633 \\
& $(0.331)$ & & $(0.369)$ & $(0.494)$ & & $(0.447)$ & $(0.262)$ \\
Alternative Income Repatriation & & 0.2694 & & & 0.0097 & & \\
$\quad$ Tax Adv. & & $(0.405)$ & & & $(0.588)$ & & \\
Tax advantage x capital constrained & & & 0.0952 & & & & \\
& & & $(0.374)$ & & & & \\
Log of total assets & -0.0087 & -0.0087 & -0.0096 & -0.0048 & -0.0049 & -0.0091 & -0.0103 \\
& $(0.038)$ & $(0.038)$ & $(0.029)$ & $(0.085)$ & $(0.085)$ & $(0.053)$ & $(0.091)$ \\
Domestic income/total assets & 0.0021 & 0.0021 & 0.0062 & 0.0100 & 0.0100 & 0.1568 & 0.0011 \\
& $(0.089)$ & $(0.096)$ & $(0.079)$ & $(0.075)$ & $(0.077)$ & $(0.019)$ & $(0.157)$ \\
Foreign income/total assets & 0.0028 & 0.0028 & 0.0052 & 0.0014 & 0.0013 & -0.0130 & 0.0030 \\
& $(0.889)$ & $(0.889)$ & $(0.820)$ & $(0.951)$ & $(0.953)$ & $(0.982)$ & $(0.913)$ \\
Market-to-book value of equity & 0.0001 & 0.0001 & 0.0001 & 0.0001 & 0.0001 & 0.0001 & 0.0001 \\
& $(0.165)$ & $(0.164)$ & $(0.184)$ & $(0.181)$ & $(0.180)$ & $(0.165)$ & $(0.171)$ \\
Leverage & -0.0039 & -0.0039 & -0.0057 & -0.0095 & -0.0096 & -0.0083 & -0.0026 \\
& $(0.825)$ & $(0.827)$ & $(0.788)$ & $(0.768)$ & $(0.767)$ & $(0.771)$ & $(0.923)$ \\
R\&D expenses/total assets & -0.0557 & -0.0557 & -0.0600 & -0.0129 & -0.0129 & -0.0506 & -0.0580 \\
& $(0.389)$ & $(0.389)$ & $(0.369)$ & $(0.929)$ & $(0.930)$ & $(0.833)$ & $(0.532)$ \\
Payout/total assets & -0.0654 & -0.0652 & -0.1106 & -0.1974 & -0.1970 & -0.3289 & -0.0479 \\
& $(0.569)$ & $(0.570)$ & $(0.487)$ & $(0.371)$ & $(0.370)$ & $(0.101)$ & $(0.778)$ \\
SD of operating income & 0.0001 & 0.0001 & 0.0001 & 0.0011 & 0.0010 & 0.0001 & 0.0001 \\
& $(0.696)$ & $(0.712)$ & $(0.645)$ & $(0.944)$ & $(0.946)$ & $(0.146)$ & $(0.790)$ \\
Intercept & 0.0123 & 0.0123 & 0.0561 & -0.0282 & -0.0284 & 0.0659 & 0.0211 \\
& $(0.969)$ & $(0.969)$ & $(0.900)$ & $(0.956)$ & $(0.955)$ & $(0.432)$ & $(0.962)$ \\
\hline Country fixed effect & yes & yes & yes & no & no & no & no \\
Industry fixed effects & yes & yes & yes & no & no & yes & yes \\
Firm fixed effects & no & no & no & yes & yes & no & no \\
\hline $\mathrm{N}$ & 6,124 & 6,124 & 6,124 & 6,124 & 6,124 & 3,594 & 2,530 \\
Adj. $R^{2}$ & 0.105 & 0.103 & 0.108 & 0.142 & 0.139 & 0.101 & 0.098 \\
\hline
\end{tabular}

This table presents the coefficients of fixed effect regressions with domestic capital expenditures to total assets as the dependent variable. The first five columns present the results for regressions, including all observations. The sixth column present results for Japanese firms, and the seventh column presents results for U.K. firms. All variables are described in Appendix A. The regressions include year, country, and industry or firm fixed effects. p-values, obtained with standard errors corrected for clustering of errors by firm, are presented in parentheses.

Another possible consequence of repatriating more profits after the enactment of the territorial system is a lower likelihood to invest in less valuable projects in foreign countries and an overall improvement in the allocation of funds across countries. Alternatively, the territorial reform might encourage foreign investments due to the removal of the repatriation tax that could encourage firms to increase foreign profits due to the added ability to employ these profits for domestic uses at no additional tax penalty. We investigate these two alternative hypotheses by estimating fixed effects Tobit regressions with foreign capital expenditures divided by total assets as the dependent variable.

Review of Financial Studies, Vol 28, No. 8 (August 2015): pg. 2250-2280. DOI. This article is (c) Oxford University Press and permission has been granted for this version to appear in e-Publications@Marquette. Oxford University Press does not grant permission for this article to be further copied/distributed or hosted elsewhere without the express permission from Oxford University Press. 
NOT THE PUBLISHED VERSION; this is the author's final, peer-reviewed manuscript. The published version may be accessed by following the link in the citation at the bottom of the page.

As for the payout regressions, we use the Honoré's (1992) LAD estimator for the firm fixed effects specifications. Table 8 presents the results.

Table 8. Foreign investments and income repatriation tax cost Dependent variable: Foreign CapEx/total assets

\begin{tabular}{lcccccc}
\hline & $(1)$ & $(2)$ & $(3)$ & $(4)$ & Japan & U.K. \\
\hline Income Repatriation Tax Advantage & -0.6367 & & -0.2984 & & -0.7795 & -0.4431 \\
& $(0.000)$ & & $(0.075)$ & & $(0.006)$ & $(0.005)$ \\
Alternative Income Repatriation & & -0.5822 & & -0.2854 & & \\
Tax Advantage & & $(0.000)$ & & $(0.078)$ & & \\
Log of total assets & 0.0086 & 0.0086 & 0.0020 & 0.0021 & 0.0051 & 0.0131 \\
& $(0.000)$ & $(0.000)$ & $(0.038)$ & $(0.035)$ & $(0.006)$ & $(0.000)$ \\
Domestic income/total assets & -0.0028 & -0.0027 & -0.0037 & -0.0037 & -0.0181 & -0.0012 \\
& $(0.536)$ & $(0.537)$ & $(0.366)$ & $(0.360)$ & $(0.425)$ & $(0.865)$ \\
Foreign income/total assets & 0.0185 & 0.0181 & 0.0056 & 0.0058 & 0.0559 & 0.0076 \\
& $(0.031)$ & $(0.037)$ & $(0.094)$ & $(0.093)$ & $(0.000)$ & $(0.176)$ \\
Market-to-book value of equity & 0.0001 & 0.0001 & 0.0001 & 0.0001 & 0.0006 & 0.0001 \\
& $(0.554)$ & $(0.611)$ & $(0.504)$ & $(0.504)$ & $(0.063)$ & $(0.693)$ \\
Leverage & -0.0024 & -0.0025 & -0.0035 & -0.0037 & -0.0042 & -0.0037 \\
& $(0.355)$ & $(0.352)$ & $(0.595)$ & $(0.574)$ & $(0.234)$ & $(0.622)$ \\
R\&D expenses/total assets & -0.0178 & -0.0172 & -0.0025 & -0.0024 & -0.0103 & -0.0019 \\
& $(0.149)$ & $(0.169)$ & $(0.860)$ & $(0.863)$ & $(0.902)$ & $(0.573)$ \\
Payout/total assets & -0.0044 & -0.041 & -0.0114 & -0.0113 & -0.0708 & -0.0109 \\
& $(0.789)$ & $(0.804)$ & $(0.383)$ & $(0.384)$ & $(0.438)$ & $(0.574)$ \\
SD of operating income & -0.0001 & -0.0001 & -0.0001 & -0.0001 & -0.0001 & -0.0001 \\
& $(0.095)$ & $(0.093)$ & $(0.000)$ & $(0.000)$ & $(0.230)$ & $(0.156)$ \\
Intercept & -0.1654 & -0.1657 & -0.1107 & -0.1107 & -0.199 & -0.3627 \\
& $(0.000)$ & $(0.000)$ & $(0.000)$ & $(0.000)$ & $(0.000)$ & $(0.000)$ \\
\hline Country fixed effect & yes & yes & no & no & no & no \\
Industry fixed effects & yes & yes & no & no & yes & yes \\
Firm fixed effects & no & no & yes & yes & no & no \\
\hline N & 4,272 & 4,272 & 4,272 & 4,272 & 2507 & 1,765 \\
Pseudo $R^{2}$ & 0.206 & 0.183 & 0.242 & 0.238 & 0.158 & 0.143 \\
\hline
\end{tabular}

This table presents the coefficients of fixed effect Tobit regressions with foreign capital expenditures to total assets as the dependent variable. The firm fixed effects specifications (3) and (4) are estimated with the Honoré's (1992) trimmed least absolute deviation (LAD) estimator. The first four columns present the results for regressions including all observations. The fifth column present results for Japanese firms, and the sixth column presents results for U.K. firms. All variables are described in Appendix A. The regressions include year, country, and industry or firm fixed effects. p-values, obtained with standard errors corrected for clustering of errors by firm, are presented in parentheses.

Both repatriation tax advantage proxies in all specifications have negative and significant coefficients consistent with our hypothesis that the exemption from repatriation taxes due to the implementation of the territorial system has significantly reduced foreign investments. The Income Repatriation Tax Advantage also has strong economic permission has been granted for this version to appear in e-Publications@Marquette. Oxford University Press does not grant permission for this article to be further copied/distributed or hosted elsewhere without the express permission from Oxford University Press. 
significance. A change of the Income Repatriation Tax Advantage coefficient from its 2006-2008 mean value of -0.0030 to zero during the 2009-2011 territorial system period causes a $9.2 \%$ decrease in foreign capex/assets in the industry fixed effects specification and a $7.1 \%$ decrease in the firm fixed effects specification, which corresponds to a decline of $\$ 17.5 \mathrm{M}$ and $\$ 13.5 \mathrm{M}$ for a multinational firm with average assets depending on the specification, everything else constant, at the median.

Overall, the results of the industry (firm) fixed effects regressions with the Income Repatriation Tax Advantage as tax variable suggest that for a multinational firm with average assets in our sample after the territorial system reform cash holdings decline by $\$ 64 \mathrm{M}(\$ 43 \mathrm{M})$, and foreign investments decline by about \$18 M ( $\$ 14$ $M)$. Net payouts, on the other hand, increase by $\$ 69 \mathrm{M}(\$ 64 \mathrm{M})$, of which between $\$ 60 \mathrm{M}(\$ 51 \mathrm{M})$ are due to an increase in dividends.

All in all, the tests discussed in this section show that the switch from a worldwide repatriation system to a territorial system had the effect of encouraging multinational firms to save more foreign cash by cutting foreign investments and to transfer larger quantities of foreign cash to their domestic country to increase corporate payouts, but not domestic investments. While firms can quickly implement changes in their payout policy, they might need a longer time to plan and bring to fruition capital investments in the domestic country after a tax law change. Another possible reason why our results do not show a rapid increase in domestic investments following the tax reform is that, contrary to the U.S. temporary tax holiday, Japanese and U.K. firms were not required to commit to new domestic investments to repatriate earnings without incurring in repatriation taxes.

\section{Robustness tests}

Because during our sample period the United Kingdom has a relatively high statutory corporate tax rate $(30 \%-26 \%)$, but one that is lower than some other countries (see Table Al), a group of U.K. firms with a majority of foreign operations in countries with higher tax rates benefitted from a tax credit upon repatriation of foreign earnings during the worldwide system period. ${ }^{20}$ This group of firms are likely to respond to the territorial tax reform in the opposite way than would permission has been granted for this version to appear in e-Publications@Marquette. Oxford University Press does not grant permission for this article to be further copied/distributed or hosted elsewhere without the express permission from Oxford University Press. 
firms facing a tax liability upon repatriation during the worldwide period. The territorial tax system reform essentially removed the repatriation tax credit enjoyed by these firms and therefore eliminated an incentive to repatriate profits for domestic uses of cash, such as dividends, share repurchases, and domestic investments. This group of firms, therefore, allows us to estimate a test in which we can compare the behavior of firms facing a tax cost with firms benefitting from a tax credit upon repatriating earnings during the worldwide system period and how these two groups reacted to the territorial reform. For this test, we limit our sample to multinational firms headquartered in the United Kingdom. We categorize firms as "Repatriation Tax Credit Firms" if the variable Income Repatriation Tax Advantage assumes a positive value for at least two of the three years of the worldwide system period. To verify if these tax credit firms behave in a different way than would firms facing a repatriation tax cost before and after the reform, we estimate regressions with the Repatriation Tax Credit Firm indicator along with the interaction variable Repatriation Tax Credit Firm x Territorial Period, which assumes the value of one for repatriation tax credit firm during the 2009-2011 territorial period.

Table 9 presents the results of these regressions. In the regression with cash/assets as the dependent variable, the coefficients of the two tax credit indicator variables show that firms enjoying a repatriation tax credit during the worldwide period hold significantly less cash than do firms facing a repatriation cost, but then they increase their cash holdings as they lose the tax credit during the territorial period. The dividend yield and payout yield regressions show that tax credit firms pay higher dividends during the worldwide period and reduce dividends during the territorial period. It is worth noting that the magnitude of the coefficients of the two indicators in the cash, dividend, and payout regressions have similar size with inverted signs suggesting that during the territorial period, after controlling for all factors affecting cash and payout policy, there is little difference in cash and payout policy between firms facing a cost or enjoying a credit during the worldwide system. This result is due to the reform effectively eliminating a tax disparity between these two types of firms. Consistent with the results of the main multivariate regressions, the coefficients of the tax variables are not significant in the domestic investment regressions. The Repatriation Tax Credit Firm coefficient in the foreign investment regression is negative and significant, permission has been granted for this version to appear in e-Publications@Marquette. Oxford University Press does not grant permission for this article to be further copied/distributed or hosted elsewhere without the express permission from Oxford University Press. 
suggesting that repatriation tax credit firms invest less abroad during the worldwide period. Even though the Repatriation Tax Credit Firm $x$ Territorial Period coefficient is not significant, the coefficients of the two indicators taken together $(=-0.0115+0.0098=-0.0017)$ suggest that the reform has essentially eliminated the effect that the worldwide system had on foreign investments.

Table 9. U.K. tax credit firms

\begin{tabular}{|c|c|c|c|c|c|c|}
\hline & Cash & Dividend & Repurchase & Payout & $\begin{array}{c}\text { Domestic } \\
\text { Capex }\end{array}$ & $\begin{array}{c}\text { Foreign } \\
\text { Capex }\end{array}$ \\
\hline \multirow[t]{2}{*}{ Repatriation tax credit firm } & -1.2817 & 0.0645 & 0.0259 & 0.0675 & 0.0131 & -0.0115 \\
\hline & $(0.018)$ & $(0.071)$ & $(0.082)$ & $(0.061)$ & $(0.202)$ & $(0.093)$ \\
\hline \multirow{2}{*}{$\begin{array}{l}\text { Repatriation tax credit firm } \\
\mathrm{x} \text { territorial period }\end{array}$} & 0.8381 & -0.0463 & -0.0132 & -0.0416 & -0.0089 & 0.0098 \\
\hline & $(0.078)$ & $(0.077)$ & $(0.103)$ & $(0.082)$ & $(0.231)$ & $(0.324)$ \\
\hline \multirow[t]{2}{*}{ Log of total assets } & -0.2824 & 0.0109 & 0.0067 & -0.0111 & -0.0045 & 0.0053 \\
\hline & $(0.000)$ & $(0.048)$ & $(0.049)$ & $(0.103)$ & $(0.400)$ & $(0.069)$ \\
\hline \multirow[t]{2}{*}{ Domestic income/total assets } & 0.8471 & 0.0061 & 0.0026 & 0.0186 & 0.0242 & 0.0017 \\
\hline & $(0.009)$ & $(0.048)$ & $(0.093)$ & $(0.968)$ & $(0.039)$ & $(0.863)$ \\
\hline \multirow[t]{2}{*}{ Foreign income/total assets } & 0.1983 & 0.0176 & 0.0051 & 0.0147 & 0.0122 & 0.0271 \\
\hline & $(0.145)$ & $(0.079)$ & $(0.091)$ & $(0.693)$ & $(0.620)$ & $(0.051)$ \\
\hline \multirow[t]{2}{*}{ Market-to-book value of equity } & 0.0007 & 0.0001 & 0.0001 & 0.0001 & 0.0001 & 0.0001 \\
\hline & $(0.576)$ & $(0.623)$ & $(0.742)$ & $(0.541)$ & $(0.952)$ & $(0.644)$ \\
\hline \multirow[t]{2}{*}{ Leverage } & -0.481 & -0.0305 & -0.0065 & -0.0370 & 0.0162 & -0.0006 \\
\hline & $(0.040)$ & $(0.099)$ & $(0.160)$ & $(0.074)$ & $(0.289)$ & $(0.945)$ \\
\hline \multirow[t]{2}{*}{ Capital expenditures/total assets } & -1.4552 & -0.0402 & -0.0452 & -0.0978 & & \\
\hline & $(0.036)$ & $(0.126)$ & $(0.034)$ & $(0.136)$ & & \\
\hline \multirow[t]{2}{*}{$\mathrm{R} \& \mathrm{D}$ expenses/total assets } & -1.8369 & -0.0214 & -0.0149 & -0.0475 & 0.0365 & -0.0036 \\
\hline & $(0.001)$ & $(0.094)$ & $(0.087)$ & $(0.034)$ & $(0.365)$ & $(0.877)$ \\
\hline \multirow[t]{2}{*}{ Payout/total assets } & -0.2867 & & & & -0.0124 & -0.0029 \\
\hline & $(0.089)$ & & & & $(0.551)$ & $(0.785)$ \\
\hline \multirow[t]{2}{*}{ SD of operating income } & -0.0016 & -0.0216 & -0.0034 & -0.0086 & 0.0347 & -0.0041 \\
\hline & $(0.614)$ & $(0.713)$ & $(0.210)$ & $(0.441)$ & $(0.052)$ & $(0.697)$ \\
\hline \multirow{2}{*}{ Intercept } & 3.2202 & -0.0447 & -0.0386 & -0.0613 & -0.4523 & 0.0426 \\
\hline & $(0.000)$ & $(0.471)$ & $(0.133)$ & $(0.455)$ & $(0.073)$ & $(0.771)$ \\
\hline Firm fixed effects & yes & yes & yes & yes & yes & yes \\
\hline$\overline{\mathrm{N}}$ & 1,438 & 1,438 & 1,438 & 1,438 & 700 & 700 \\
\hline Adj. $R^{2}$ & 0.149 & 0.171 & 0.169 & 0.187 & 0.099 & 0.102 \\
\hline
\end{tabular}

This table presents the coefficients of fixed effect regressions with In(cash/assets), dividend yield, net repurchase yield, net payout yield, domestic capital expenditures/assets, and foreign capital expenditures/assets as the dependent variables. The sample consists only of U.K. multinational firms. The main explanatory variables are (1) an indicator variable equal to one if the firm received tax credit upon repatriation during the worldwide system period and (2) an interaction variable between the repatriation tax credit firm dummy and an indicator variable equal to one for the 2009-2011 territorial system period. All variables are described in Appendix A. The regressions include firm fixed effects. $p$-values, obtained with standard errors corrected for clustering of errors by firm, are presented in parentheses. 
As for most countries around the world, both Japan and the United Kingdom experienced a deep recession in 2008 and 2009. As a robustness test to control for business cyclicality and the effects of the recession, we replicate our multivariate tests, excluding the recessionary years' observations. All the tax variable coefficients maintain the same sign and are statistically significant (with the exception of those for the domestic investments regressions). The significance is sometimes at a lower level because of the smaller sample size, which reduces the power of our tests.

In the main regressions discussed in the previous section, we control for year and industry effects in most specifications. However, there could be specific temporal trends by industry that might affect some of our results. To control for this possibility, we re-estimate our multivariate tests, including industry $\mathrm{x}$ year fixed effects in unreported specifications. The coefficients of the Income Repatriation Tax Advantage maintain their significance. Overall, this test show that our results are robust to the inclusion of annual industry effects. ${ }^{21}$

In our multivariate analysis, consistent with the payout literature (e.g., Hoberg and Prabhala (2009); Grullon et al. (2011)) and corporate practices, we measure payout activity with yield variables by dividing dividends, share repurchases, and total net payout by firms' market value. However, the market value of many companies experienced large fluctuations during our sample period due to the recessionary years. To test the robustness of our payout results to changes in market value we re-estimate our payout regressions by substituting the yield dependent variables with payouts divided by total assets. Table 10 presents the results. The significance of the tax advantage variables for the different specifications is comparable with that obtained from the payout yield regressions presented in the main multivariate section. 
NOT THE PUBLISHED VERSION; this is the author's final, peer-reviewed manuscript. The published version may be accessed by following the link in the citation at the bottom of the page.

Table 10. Payouts to assets and income repatriation tax cost

\begin{tabular}{lcccccc} 
& \multicolumn{2}{c}{ Dividends/assets } & \multicolumn{2}{c}{ Repurchases/assets } & \multicolumn{2}{c}{ Total payout/assets } \\
\hline Income repatriation tax advantage & 0.4473 & 0.2207 & 0.2208 & 0.0938 & 0.4645 & 0.1192 \\
& $(0.021)$ & $(0.001)$ & $(0.045)$ & $(0.046)$ & $(0.025)$ & $(0.028)$ \\
Log of total assets & 0.0043 & 0.0007 & 0.0029 & 0.0025 & 0.0045 & 0.0007 \\
& $(0.000)$ & $(0.087)$ & $(0.000)$ & $(0.076)$ & $(0.000)$ & $(0.084)$ \\
Domestic income/total assets & 0.1302 & 0.0424 & 0.074 & 0.0383 & 0.1544 & 0.0547 \\
& $(0.000)$ & $(0.000)$ & $(0.000)$ & $(0.001)$ & $(0.000)$ & $(0.000)$ \\
Foreign income/total assets & 0.1565 & 0.0289 & 0.0954 & 0.0729 & 0.1893 & 0.0528 \\
& $(0.000)$ & $(0.001)$ & $(0.000)$ & $(0.000)$ & $(0.000)$ & $(0.000)$ \\
Market-to-book value of equity & -0.0001 & -0.0001 & -0.0001 & -0.0001 & -0.0001 & -0.0002 \\
& $(0.110)$ & $(0.000)$ & $(0.176)$ & $(0.144)$ & $(0.001)$ & $(0.000)$ \\
Leverage & -0.0316 & -0.004 & -0.0206 & -0.0011 & -0.0352 & -0.0012 \\
& $(0.000)$ & $(0.078)$ & $(0.000)$ & $(0.193)$ & $(0.000)$ & $(0.088)$ \\
Capital expenditures/total assets & -0.0087 & -0.0243 & -0.0462 & -0.0923 & -0.0178 & -0.0044 \\
& $(0.500)$ & $(0.031)$ & $(0.000)$ & $(0.000)$ & $(0.220)$ & $(0.757)$ \\
R\&D expenses/total assets & -0.1416 & -0.036 & -0.0922 & -0.0134 & -0.1681 & -0.0092 \\
& $(0.000)$ & $(0.287)$ & $(0.000)$ & $(0.781)$ & $(0.000)$ & $(0.814)$ \\
SD of operating income & -0.0010 & -0.0010 & -0.0010 & -0.0025 & -0.0010 & -0.0025 \\
& $(0.112)$ & $(0.199)$ & $(0.011)$ & $(0.197)$ & $(0.465)$ & $(0.011)$ \\
Intercept & -0.1472 & -0.0342 & -0.1397 & -0.0746 & -0.1530 & -0.0874 \\
& $(0.998)$ & $(0.999)$ & $(0.999)$ & $(0.982)$ & $(0.998)$ & $(0.574)$ \\
\hline Country fixed effect & yes & no & yes & no & yes & no \\
Industry fixed effects & yes & no & yes & no & yes & no \\
Firm fixed effects & no & yes & no & yes & no & yes \\
\hline $\mathrm{N}$ & 8,415 & 8,415 & 8,415 & 8,415 & 8,415 & 8,415 \\
Pseudo $R^{2}$ & 0.437 & 0.512 & 0.324 & 0.368 & 0.411 & 0.503 \\
\hline
\end{tabular}

This table presents the coefficients of fixed effect Tobit regressions with dividends to assets, net share repurchases to assets, and net total payouts to assets as the dependent variables. All variables are described in Appendix A. The regressions include year, country, and industry or firm fixed effects. pvalues, obtained with standard errors corrected for clustering of errors by firm, are presented in parentheses.

\section{Conclusions}

Countries rarely make clear-cut changes to their taxation rules. In this study we exploit one of those rare opportunities offered by the decision of Japan and the United Kingdom in 2009 to switch from a worldwide to a territorial system for the taxation of repatriated foreign corporate income. We find that this change had broad and significant repercussions on corporate financial decisions.

The switch from a tax credit repatriation system to a territorial system in Japan and the United Kingdom offered multinational firms residing in these two countries the ability to repatriate foreign income at no additional or significantly lower tax costs. Overall, the results of this study suggest that the removal of this tax disadvantage when repatriating earnings had the effect of encouraging multinational firms

Review of Financial Studies, Vol 28, No. 8 (August 2015): pg. 2250-2280. DOI. This article is (c) Oxford University Press and permission has been granted for this version to appear in e-Publications@Marquette. Oxford University Press does not grant permission for this article to be further copied/distributed or hosted elsewhere without the express permission from Oxford University Press. 
NOT THE PUBLISHED VERSION; this is the author's final, peer-reviewed manuscript. The published version may be accessed by following the link in the citation at the bottom of the page.

to save more cash abroad by cutting foreign investments and to transfer larger quantities of foreign cash to the domestic country to increase corporate payouts rather than domestic investments. The ability to use more cash from the firms' headquarters location for payouts had the additional effect of decreasing consolidated cash holdings. The results of this paper may assist the decision-making process of policy makers in the United States and other countries that are currently adopting a worldwide system and are considering a change in their tax repatriation rule. In more general terms, this study underlines how a permanent change in the corporate tax code can have strong, long-standing consequences for corporate financial policies that ultimately affect shareholder wealth and the level of employment in domestic and foreign countries. 
NOT THE PUBLISHED VERSION; this is the author's final, peer-reviewed manuscript. The published version may be accessed by following the link in the citation at the bottom of the page.

\section{Appendix}

Table A1. Country corporate tax rate

\begin{tabular}{|c|c|c|c|c|c|c|}
\hline \multirow[b]{2}{*}{ Country } & \multicolumn{6}{|c|}{ Year } \\
\hline & 2006 & 2007 & 2008 & 2009 & 2010 & 2011 \\
\hline $\begin{array}{c}\text { United Arab } \\
\text { Emirates }\end{array}$ & 55 & 55 & 55 & 55 & 55 & 55 \\
\hline Kuwait & 55 & 55 & 55 & 15 & 15 & 15 \\
\hline Japan & 40.69 & 40.69 & 40.69 & 40.69 & 40.69 & 40.69 \\
\hline United States & 40 & 40 & 40 & 40 & 40 & 40 \\
\hline Germany & 38.34 & 38.36 & 29.51 & 29.44 & 29.41 & 29.37 \\
\hline Italy & 37.25 & 37.25 & 31.4 & 31.4 & 31.4 & 31.4 \\
\hline South Africa & 36.89 & 36.89 & 34.55 & 34.55 & 34.55 & 34.55 \\
\hline Canada & 36.1 & 36.1 & 33.5 & 33 & 31 & 28 \\
\hline Argentina & 35 & 35 & 35 & 35 & 35 & 35 \\
\hline Colombia & 35 & 34 & 33 & 33 & 33 & 33 \\
\hline Philippines & 35 & 35 & 35 & 30 & 30 & 30 \\
\hline Spain & 35 & 32.5 & 30 & 30 & 30 & 30 \\
\hline Tunisia & 35 & 30 & 30 & 30 & 30 & 30 \\
\hline Qatar & 35 & 35 & 35 & 35 & 10 & 10 \\
\hline Brazil & 34 & 34 & 34 & 34 & 34 & 34 \\
\hline Venezuela & 34 & 34 & 34 & 34 & 34 & 34 \\
\hline Belgium & 33.99 & 33.99 & 33.99 & 33.99 & 33.99 & 33.99 \\
\hline India & 33.66 & 33.99 & 33.99 & 33.99 & 33.99 & 32.44 \\
\hline France & 33.33 & 33.33 & 33.33 & 33.33 & 33.33 & 33.33 \\
\hline New Zealand & 33 & 33 & 30 & 30 & 30 & 28 \\
\hline China & 33 & 33 & 25 & 25 & 25 & 25 \\
\hline Israel & 31 & 29 & 27 & 26 & 25 & 24 \\
\hline Zimbabwe & 30.9 & 30.9 & 30.9 & 30.9 & 25.75 & 25.75 \\
\hline Australia & 30 & 30 & 30 & 30 & 30 & 30 \\
\hline Nigeria & 30 & 30 & 30 & 30 & 30 & 30 \\
\hline Peru & 30 & 30 & 30 & 30 & 30 & 30 \\
\hline Thailand & 30 & 30 & 30 & 30 & 30 & 30 \\
\hline United Kingdom & 30 & 30 & 30 & 28 & 28 & 26 \\
\hline Uruguay & 30 & 30 & 25 & 25 & 25 & 25 \\
\hline Luxembourg & 29.63 & 29.63 & 29.63 & 28.59 & 28.59 & 28.8 \\
\hline Netherlands & 29.6 & 25.5 & 25.5 & 25.5 & 25.5 & 25 \\
\hline Mexico & 29 & 28 & 28 & 28 & 30 & 30 \\
\hline Greece & 29 & 25 & 25 & 25 & 24 & 20 \\
\hline Norway & 28 & 28 & 28 & 28 & 28 & 28 \\
\hline Sweden & 28 & 28 & 28 & 26.3 & 26.3 & 26.3 \\
\hline Denmark & 28 & 25 & 25 & 25 & 25 & 25 \\
\hline Malaysia & 28 & 27 & 26 & 25 & 25 & 25 \\
\hline Vietnam & 28 & 28 & 28 & 25 & 25 & 25 \\
\hline Portugal & 27.5 & 25 & 25 & 25 & 25 & 25 \\
\hline Korea, Republic of & 27.5 & 27.5 & 27.5 & 24.2 & 24.2 & 22 \\
\hline Finland & 26 & 26 & 26 & 26 & 26 & 26 \\
\hline Austria & 25 & 25 & 25 & 25 & 25 & 25 \\
\hline Ukraine & 25 & 25 & 25 & 25 & 25 & 25 \\
\hline Ecuador & 25 & 25 & 25 & 25 & 25 & 24 \\
\hline Slovenia & 25 & 23 & 22 & 21 & 20 & 20 \\
\hline Taiwan & 25 & 25 & 25 & 25 & 17 & 17 \\
\hline Russia & 24 & 24 & 24 & 20 & 20 & 20 \\
\hline Czech Republic & 24 & 24 & 21 & 20 & 19 & 19 \\
\hline Switzerland & 21.3 & 21.32 & 21.17 & 21.17 & 21.17 & 21.17 \\
\hline Croatia & 20 & 20 & 20 & 20 & 20 & 20 \\
\hline Egypt & 20 & 20 & 20 & 20 & 20 & 20 \\
\hline Saudi Arabia & 20 & 20 & 20 & 20 & 20 & 20 \\
\hline Turkey & 20 & 20 & 20 & 20 & 20 & 20 \\
\hline Singapore & 20 & 20 & 18 & 18 & 17 & 17 \\
\hline
\end{tabular}

Review of Financial Studies, Vol 28, No. 8 (August 2015): pg. 2250-2280. DOI. This article is (C) Oxford University Press and permission has been granted for this version to appear in e-Publications@Marquette. Oxford University Press does not grant permission for this article to be further copied/distributed or hosted elsewhere without the express permission from Oxford University Press. 


\begin{tabular}{lllllll} 
& \multicolumn{7}{c}{ Year } \\
\cline { 2 - 7 } Country & 2006 & 2007 & 2008 & 2009 & 2010 & 2011 \\
\hline Poland & 19 & 19 & 19 & 19 & 19 & 19 \\
Slovak Republic & 19 & 19 & 19 & 19 & 19 & 19 \\
Iceland & 18 & 18 & 15 & 15 & 18 & 20 \\
Hong Kong & 17.5 & 17.5 & 16.5 & 16.5 & 16.5 & 16.5 \\
Chile & 17 & 17 & 17 & 17 & 17 & 20 \\
Hungary & 16 & 16 & 16 & 16 & 19 & 19 \\
Romania & 16 & 16 & 16 & 16 & 16 & 16 \\
Latvia & 15 & 15 & 15 & 15 & 15 & 15 \\
Lithuania & 15 & 15 & 15 & 20 & 15 & 15 \\
Bulgaria & 15 & 10 & 10 & 10 & 10 & 10 \\
Ireland & 12.5 & 12.5 & 12.5 & 12.5 & 12.5 & 12.5 \\
Bosnia and & 10 & 10 & 10 & 10 & 10 & 10 \\
$\quad$ Herzegovina & & & & & & \\
Paraguay & 10 & 10 & 10 & 10 & 10 & 10 \\
Serbia & 10 & 10 & 10 & 10 & 10 & 10 \\
Montenegro & 9 & 9 & 9 & 9 & 9 & 9 \\
Bahamas & 0 & 0 & 0 & 0 & 0 & 0 \\
Bahrain & 0 & 0 & 0 & 0 & 0 & 0 \\
Bermuda & 0 & 0 & 0 & 0 & 0 & 0 \\
Cayman Islands & 0 & 0 & 0 & 0 & 0 & 0 \\
\hline
\end{tabular}

Local corporate tax rate are averaged at the country level and added to the statutory country tax rate. Countries are ordered by descending 2006 tax rate. Source: KPMG.

\section{Appendix A}

Variable definitions

Variable

Alternative Income Repatriation Tax Advantage

Log (Cash/Net Assets)

Capital Constrained

Capital Expenditures/Total Assets

Dividend Payout Yield

\section{Definition}

The product of a firm's foreign pretax income and its country corporate tax rate minus foreign taxes paid. The maximum of this difference or zero is then divided by total firm assets and the sign is inverted. This variable is set to zero between 2009 and 2011

Natural logarithm of cash plus marketable securities divided by total assets minus cash and marketable securities

Percentage of the four previous years during which the firm had operating cash flows (operating profits minus taxes) below capital expenditures

Total capital expenditures divided by total assets

Firm's annual dividend payments divided by its yearend market value 
NOT THE PUBLISHED VERSION; this is the author's final, peer-reviewed manuscript. The published version may be accessed by following the link in the citation at the bottom of the page.

Variable

Domestic Capex/Total Assets

Domestic Income/Total Assets

Foreign Capex/Total Assets

Foreign Income/Total Assets

Income Repatriation Tax Advantage

Leverage Log of Total Assets Net Payout Yield

R\&D Expenses/Total Assets

Market-to-Book Value of Equity

St. Dev. of Operating Income

Tobin's Q

Total Income/Total Assets

\section{Definition}

Domestic capital expenditures divided by total assets

Domestic earnings before interest and taxes divided by total assets

Foreign capital expenditures divided by total assets

Foreign earnings before interest and taxes divided by total assets.

The product of a firm's foreign pre-tax income and its effective tax rate minus foreign taxes paid. The maximum of this difference or zero is then divided by total firm assets and the sign is inverted. . This variable is set to zero between 2009 and 2011

(Long-term debt + short-term debt)/total assets

Natural logarithm of the firm assets

firm's annual total net payout (dividends plus repurchases less equity issuances) divided by its year-end market value

Research and Development expenses, set to zero if missing, divided by total assets

Ratio of the market value to the book value of a firm's equity

Standard deviation of the firm's annual operating income during the sample period

Total assets plus market value of equity minus book value of equity, all divided by total assets Consolidated earnings before interest and taxes divided by total assets

All the financial statement data used to construct the variables are retrieved from Worldscope and expressed in U.S. dollars.

We wish to thank David Denis (the editor), Randy Heron, Brandon Julio, Takeshi Nishikawa, Anthony Pennington-Cross, Sarah Peck, an anonymous referee, and seminar participants at Marquette University, University of Colorado Denver and the FMA 2013 meeting for helpful comments and discussions.

\section{References}

Altshuler, R., Grubert, H. .

Repatriation taxes, repatriation strategies and multinational financial policy, Journal of Public Economics, 2002, vol. 87 (pg. 73-107) 
Arena, M. P., Julio, B.. The effects of securities class action litigation on corporate liquidity and investment policy, Journal of Financial and Quantitative Analysis, 2014

Advance Access published March 14, 2014, 10.1017/S0022109014000076.

Blouin, J., Krull, L. Bringing it home: A study of the incentives surrounding the repatriation of foreign earnings under the American J obs Creation Act of 2004, Journal of Accounting

Research, 2009, vol. 47 (pg. 1027-59)

Desai, M. A., Foley, C. F., Hines, J. R. J r. Repatriation taxes and dividend distortions, National tax journal, 2001, vol. 54 (pg. 829-51) Desai, M. A., Foley, C. F., Hines, J. R. Jr. Dividend policy inside the multinational firm, Financial Management, 2007, vol. 36 (pg. 5-26) Dharmapala, D., Foley, C. F., Forbes, K. J.. Watch what I do, not what I say: The unintended consequences of the homeland investment act, Journal of Finance, 2011, vol. 66 (pg. 753-87)

Faulkender, M., Petersen, M. Investment and capital constraints:

Repatriation under the American jobs creation acts, Review of Financial Studies, 2012, vol. 25 (pg. 3351-88)

Foley, C. F., Hartzell, J. C., Titman, S., Twite, G. Why do firms hold so much cash? A tax-based explanation, Journal of Financial

Economics, 2007, vol. 86 (pg. 579-607)

Graham, J. R., Eckbo, B. Espen. Taxes and corporate finance, Handbook of corporate finance, 2008. Amsterdam NorthHolland

Graham, J. R., Hanlon, M., Shevlin, T. Real effects of accounting rules: Evidence from multinational firms investment location and profit repatriation decisions, J ournal of Accounting Research, 2011, vol. 49 (pg. 137-85)

Grubert, H., Mutti, J., Taxing international business income: Dividend exemption versus the current system, 2001 Washington, DC:

American Enterprise Institute Press

Grullon, G., Paye, B., Underwood, S., Weston, J. P. Has the propensity to pay out declined?, Journal of Financial and Quantitative Analysis, 2011, vol. 46 (pg. 1-24)

Hanlon, M., Lester, R., Verdi, R. The effect of repatriation tax costs on U.S. multinational investment, Journal of Financial Economics, Forthcoming 
Hartman, D. G. Tax policy and foreign direct investment, Journal of Public Economics, 1985, vol. 26 (pg. 107-21)

Hoberg, G., Prabhala, N. R. Disappearing dividends, catering, and risk, Review of Financial Studies, 2009, vol. 22 (pg. 79-116)

Honoré, B. E. Trimmed LAD and least squares estimation of truncated and censored regression models with fixed effects, Econometrica, 1992 , vol. 60 (pg. 533-65)

Landau, T., Tokuhiro, T., Muraoka, K., Kobayashi, S. Japan issues proposed 2009 tax reforms, J ournal of International

Taxation, 2009, vol. 20 (pg. 15-9)

Markle, K. 2013. A comparison of the tax-motivated income shifting of multinationals in territorial and worldwide countries. Working Paper, University of Waterloo.

Opler, T., Pinkowitz, L., Stulz, R., Williamson, R. The determinants and implications of corporate cash holdings, J ournal of

Finance, 1999, vol. 52 (pg. 3-46)

Rau, P. R., Vermaelen, T. Regulation, taxes, and share repurchases in the United Kingdom, Journal of Business, 2002, vol. 75 (pg. 245-82) Skinner, D. J. The evolving relation between earnings, dividends, and stock repurchases, Journal of Financial Economics, 2008, vol. 87 (pg. 582-609)

${ }^{1}$ See, for example, "More profits parked offshore," The Wall Street Journal, March 11, 2013, "Corporate taxes, the myths and facts," The Wall Street J ournal, October 12, 2012, "Obama vs. Volcker, et al. The President's advisers agree with Romney on a territorial tax reform," The Wall Street J ournal, October 4, 2012, "Why investors can't get more cash out of U.S. companies," The Wall Street J ournal, February 19, 2011, and "Escaping the shakedown," The Economist, July 4, 2009.

${ }^{2}$ In some territorial system countries, the exemption is set at $95 \%$ instead of being full.

3 The foreign country also levies a withholding tax on dividends (earnings) transferred to the parent country.

4 Tax Foundation Fiscal Fact No. 335.

${ }^{5}$ Houlder, V., "Tax move aims to check business exodus," Financial Times, December 10, 2008. Tax Foundation Fiscal Fact No. 336. 
NOT THE PUBLISHED VERSION; this is the author's final, peer-reviewed manuscript. The published version may be accessed by following the link in the citation at the bottom of the page.

6 "WPP, publisher weigh end to tax exile from U.K.," The Wall Street Journal, March 25, 2010.

7 Source: Thomson Reuters Worldscope.

${ }^{8}$ As stated by the 2013 IMF Fiscal Monitor Report Survey, these tax avoidance techniques are implemented by multinational firms in both advanced and developing economies. However, the problem is less acute in Japan because Tax Heaven Counter Measure Laws effectively limit tax avoidance schemes via tax heavens.

9 Let us consider a J apanese multinational firm with a cost of capital of $11 \%$. This firm needs to repatriate cash to invest in a project that will generate $\$ 150 \mathrm{M}$ in cash flows next year and will require an investment of $\$ 100 \mathrm{M}$ this year (the NPV is therefore $\$ 35.1 \mathrm{M}$ ). The cash could be repatriated from a Dutch subsidiary. The Dutch subsidiary also has an investment opportunity that could generate $\$ 135 \mathrm{M}$ next year and requires a \$100 M investment this year (the NPV is $\$ 21.6 \mathrm{M})$. In the absence of repatriation taxes, the cash would be repatriated to invest in the more lucrative domestic project. Under the worldwide tax system, the foreign project would be chosen instead. The statutory corporate tax in the Netherlands is $25.5 \%$, whereas it is $40.69 \%$ in Japan. The $15.19 \%$ difference on the $\$ 100 \mathrm{M}$ would be paid upon repatriation. Therefore, approximately $\$ 118 \mathrm{M}$ would need to be repatriated to have $\$ 100 \mathrm{M}$ after tax to invest in the domestic project $(118 *(1-0.1519)=100)$. Effectively, therefore, the domestic project requires an investment of $\$ 118 \mathrm{M}$, reducing the NPV to $\$ 17.1 \mathrm{M}$, which is lower than the NPV of the foreign project. Hartman (1985) argues that under the worldwide system if the aftertax rate of return abroad is higher (lower) than the domestic net rate of return, the firm would invest abroad and repatriate in the following period (repatriate immediately and invest domestically). However, if there is an expectation of a tax holiday or a territorial tax system reform in one of the following periods, the firm is more likely to reinvest in foreign projects even when their returns are lower, consistent with our hypothesis and numerical example.

10 Worldscope provides data about foreign assets, foreign capital expenditures, foreign income, and foreign income taxes for firms with foreign operations.

${ }^{11}$ We include these tax-credit firms in one of our robustness tests. 12 We calculate the effective domestic tax rate by dividing domestic income taxes by pretax domestic income. Foreign taxes include also

Review of Financial Studies, Vol 28, No. 8 (August 2015): pg. 2250-2280. DOI. This article is (c) Oxford University Press and permission has been granted for this version to appear in e-Publications@Marquette. Oxford University Press does not grant permission for this article to be further copied/distributed or hosted elsewhere without the express permission from Oxford University Press. 
any possible withholding taxes on dividends (earnings transferred to the domestic country) levied by the subsidiary country.

13 The proportion of U.K. dividend payer to nonpayer in our sample is 49: 51

14 We report these aggregate figures purely for illustrative purposes. The reported numbers are affected by any change in the number of multinational firms over the years and, most of all, changes in firm characteristics and macroeconomic conditions during and after the recession.

15 The only exception is the graph of foreign capital expenditures, which just reports the multinational firms' annual median values. 16 In unreported results, we also repeat all of our tests using a difference-in-differences (DID) estimation approach, in which we compare changes in financial policy variables for a treated group of companies that are affected by the tax law change (i.e., multinational firms) with a control group of companies that are not affected by the tax change (i.e., purely domestic firms). The results are qualitatively identical.

17 We check for the robustness of our results by scaling payouts by assets rather than by market values in regressions that are presented in Table 10.

18 Refer to Rau and Vermaelen (2002) for a detailed discussion of U.K. regulations on share repurchases.

19 For the domestic firms in our sample, domestic capital expenditures coincide with consolidated capital expenditures.

20 When we include those firms in our sample, the results do not significantly change. These results are available upon request.

21 The results of these tests are available upon request. 